Review

\title{
Dihydroartemisinin: A Potential Natural Anticancer Drug
}

\author{
Xiaoshuo Dai ${ }^{1 \#}$, Xiaoyan Zhang ${ }^{1,2,3 \#, ~ W e i ~ C h e n ~}{ }^{1,2}$, Yihuan Chen" ${ }^{1}$, Qiushuang Zhang ${ }^{1}$, Saijun Mo ${ }^{1,2}$, Jing \\ $\mathrm{Lu}^{1,2,3 凶}$ \\ 1. Department of Pathophysiology, School of Basic Medical Sciences, Zhengzhou University, Zhengzhou, Henan Province 450001, PR China \\ 2. Collaborative Innovation Center of Henan Province for Cancer Chemoprevention, Zhengzhou University, Zhengzhou, Henan Province 450001, PR China \\ 3. State Key Laboratory of Esophageal Cancer Prevention \& Treatment, Zhengzhou University, Zhengzhou, Henan Province 450052, PR China \\ \#These authors contributed equally to this work. \\ $\square$ Corresponding author: Dr Jing Lu, Department of Pathophysiology, School of Basic Medical Sciences, Zhengzhou University, No.100 Science Road, \\ Zhengzhou, Henan Province 450001, PR China. Email: lujing@zzu.edu.cn
}

(c) The author(s). This is an open access article distributed under the terms of the Creative Commons Attribution License (https://creativecommons.org/licenses/by/4.0/). See http://ivyspring.com/terms for full terms and conditions.

Received: 2020.07.06; Accepted: 2020.12.08; Published: 2021.01.16

\begin{abstract}
Dihydroartemisinin (DHA) is an active metabolite of artemisinin and its derivatives (ARTs), and it is an effective clinical drug widely used to treat malaria. Recently, the anticancer activity of DHA has attracted increasing attention. Nevertheless, there is no systematic summary on the anticancer effects of DHA. Notably, studies have shown that DHA exerts anticancer effects through various molecular mechanisms, such as inhibiting proliferation, inducing apoptosis, inhibiting tumor metastasis and angiogenesis, promoting immune function, inducing autophagy and endoplasmic reticulum (ER) stress. In this review, we comprehensively summarized the latest progress regarding the anticancer activities of DHA in cancer. Importantly, the underlying anticancer molecular mechanisms and pharmacological effects of DHA in vitro and in vivo are the focus of our attention. Interestingly, new methods to improve the solubility and bioavailability of DHA are discussed, which greatly enhance its anticancer efficacy. Remarkably, DHA has synergistic anti-tumor effects with a variety of clinical drugs, and preclinical and clinical studies provide stronger evidence of its anticancer potential. Moreover, this article also gives suggestions for further research on the anticancer effects of DHA. Thus, we hope to provide a strong theoretical support for $\mathrm{DHA}$ as an anticancer drug.
\end{abstract}

Key words: Dihydroartemisinin; Cancer; Proliferation; Apoptosis; Combination medication; Clinical trail

\section{Introduction}

Artemisinin, which is derived from the annual Compositae family member Artemisia annua L., has been used as a traditional Chinese medicine for more than 2,000 years, and dihydroartemisinin (DHA) is the first generation derivative of this compound. Artemisinin and its derivatives (ARTs) have cured more than one million malaria patients [1], and Tu Youyou, who made outstanding contributions to this field, has won several awards, including the Lasker-DeBakey Clinical Research Award in 2011 and the Nobel Prize in Medicine or Physiology in 2015 [2]. In 1973, Tu Youyou's research group synthesized DHA by reducing artemisinin with sodium borohydride. The hydroxyl group in the structure of
DHA not only improved the antimalarial activity but also served as an entry point for the synthesis of a series of ARTs. The antimalarial drugs developed based on artemisinin include artesunate, artemether and arteether [3]. The result of drug metabolism study shows that the primary active metabolites of artesunate, artemether and arteether is DHA, which indicates that these drugs primarily play a role in vivo through the production of DHA (the original drug) [4].

DHA, with a molecular formula of $\mathrm{C}_{15} \mathrm{H}_{24} \mathrm{O}_{5}$ and a molecular weight of 284.35 (Figure 1), has been demonstrated to be an effective and fast-acting antimalarial drug with low toxicity. Compared with 
A

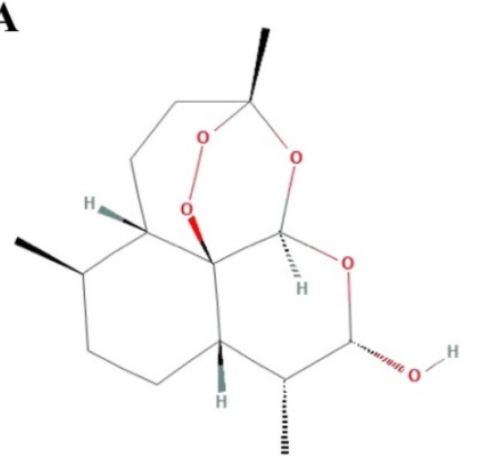

B

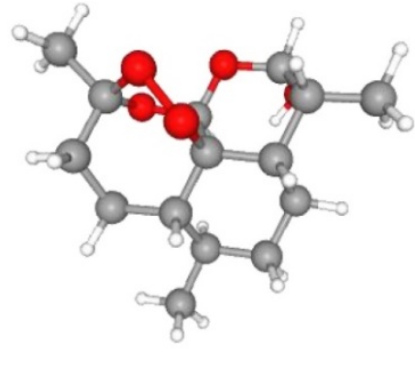

Figure 1. Chemical structures of dihydroartemisinin. (A) 2D structure. (B) 3D conformation.

artemisinin, DHA has better water solubility and stronger antimalarial activity, with antimalarial efficacy that is more than 10 times that of artemisinin. In addition, the recurrence rate of disease after treatment with DHA is as low as $1.95 \%$. After the huge success of DHA in treating malaria in the early 1990s, Tu Youyou's group began to explore new indications for DHA, and made great progress in the research of systemic lupus erythematosus [5], which suggests that DHA may have other potential indications besides its anti-malaria effects.

Cancer is the largest threat to global human health [6]. Currently, radiation therapy, chemotherapy and combination therapy are the main methods in tumor treatment [7]. However, chemotherapy and radiotherapy have notable toxicity and side effects on healthy tissues, which adversely affect the effect of treatment to some extent [8]. Therefore, there is an urgent need to develop new and effective anti-tumor drugs. It is worth noting that DHA has received increasing attention for its anticancer function due to its low toxicity and known safety. This review provides a comprehensive overview of anticancer roles of DHA, highlights the molecular mechanisms and pharmacological effects in vitro and in vivo as well as combination medication, discusses the improvement designs and clinical trials, and hopes to provide reference and inspiration for further exploration of DHA.

\section{The anticancer effects of DHA}

DHA has displayed anticancer effects on many types of tumors, such as lung cancer, breast cancer, prostate cancer, ovarian cancer and digestive system tumors. In general, DHA has been proven to have many anticancer effects, including inhibiting proliferation, inducing apoptosis, inhibiting tumor metastasis and angiogenesis, promoting immune function, inducing autophagy and endoplasmic reticulum (ER) stress (Figure 2). Herein, we systematically summarized the anticancer effects of DHA, with emphasis on the pharmacological effects and molecular mechanisms, so as to make a brief description of the anticancer effects of DHA.

\section{Inhibition of proliferation}

Cell division is necessary for the growth and repair of normal cells, however, uncontrolled cell division is one of the basic characteristics of cancer cells [9]. In general, DNA damage induced by drug would greatly affect cell integrity, interrupt the process of cell replication and division, and ultimately lead to cell cycle arrest and cell death. DHA has been shown to have powerful anti-tumor effects by inhibiting cancer cell proliferation in vitro and in vivo.

Cell cycle is the basic process of cell life, and the arrest of cell cycle can directly inhibit cell growth. Haijun Sun et al. observed that DHA inhibited the growth of gastric cancer cells (MGC803, BGC823 and SGC7901) with downregulating the expression of some proliferation markers (PCNA, Cyclin E and Cyclin D1), besides, DHA was also shown to be capable of inducing cell cycle arrest in the G1 phase [10]. Furthermore, DHA upregulated the expression of Bax and led to caspase- 9 activation, and downregulated the expression of Bcl-2, Bcl- $\mathrm{x}_{\mathrm{L}}$, Cyclin E, CDK2 and CDK4, which led to esophageal cancer cell cycle arrest [11]. Kui Liao et al. observed that DHA inhibited the growth of A549 cells by inhibiting the protein kinase $B$ (AKT)/glycogen synthase kinase-3 $\beta$ (Gsk3 $\beta$ )/Cyclin D1 signaling pathway and led to cell cycle arrest in the G1 phase [12]. Besides, DHA could inhibit the proliferation of hepatocellular carcinoma (HCC) cells by inducing cell cycle arrest in G2/M phase [13].

Remarkably, DHA also has strong anti-tumor effects in vivo. DHA could inhibit the growth of SGC7901 xenograft model, as well as Eca109 and Ec9706 xenograft tumors [10, 14]. Furthermore, treating mice with DHA at a dose of $20 \mathrm{mg} / \mathrm{kg}$ could effectively inhibit colon tumor growth compared to those treated with the control regimen [15]. Moreover, Peng Han et al. firstly revealed that knocking down the small GTPase Rac1 could strengthen the growth inhibition and cell cycle arrest induced by DHA in HCT116 and RKO colon cancer cell lines. Besides, when DHA was combined with Rac1 siRNA in vivo, it exhibited a significantly enhanced anti-tumor effect. In summary, Rac1 siRNA could promote the anticancer effect of DHA towards colon cancer by inhibiting nuclear factor kappa B (NF-kB) activation [16] (Figure 3). 




Figure 2. Synopsis of the mechanisms of dihydroartemisinin action against tumor cells.

Excessive reactive oxygen species (ROS) will exert a toxic effect on cell and affect the growth of normal cells. Diancheng Wang et al. found that DHA could increase the level of ROS in cells, thereby exerting a cytotoxic effect in cancer cells. When treated with kidney form of glutaminase (GLS1) inhibitor 968, ROS could not be eliminated in HCC cells, which made HCC cells more sensitive to DHA-mediated cytotoxicity. Hence, these results provided a basis for the clinical treatment of liver cancer by targeting glutamine metabolism and binding the ROS generator DHA [17]. Interestingly, an investigation by Tao Su et al. revealed DHA could inhibit the growth of $H$. pylori and gastric cancer cells by NF-kB signaling. Besides, DHA suppressed $H$. pylori adhesion to the gastric cancer cells and reduced the H. pylori-enhanced ROS production, and may have a therapeutic effect on $\mathrm{H}$. pylori-induced gastric cancer [18].

\section{Induction of apoptosis}

Abnormal cell proliferation is related to the disorder of apoptosis regulation, and the reduction or loss of apoptosis ability can lead to the infinite proliferation and metastasis of tumor cells. In general, tumor cells can escape from apoptosis and keep on survival and growth by down-regulating pro-apoptotic factors and up-regulating anti-apoptotic factors [19]. Apoptosis pathways include exogenous pathways mediated by death receptors and endogenous pathways mediated by mitochondria.

Current studies have shown that DHA can significantly induce apoptosis of tumor cells in vitro and in vivo. Haiting Mao et al. studied that DHA effectively inhibited the proliferation of T-47D breast cancer cells by increasing the protein expression of caspase-8, cleaved caspase-9 and Bim, activating Bid and inducing cytochrome $\mathrm{c}$ release. These results indicated that the mitochondrial pathway exerted an important effect in the process of DHA-induced breast cancer cell apoptosis, and the imbalance of Bim/Bcl-2 interactions promoted this process [20] (Figure 3). Bim and a small amount of Noxa could activate Bak-mediated intrinsic apoptotic pathways as upstream mediators [21]. Furthermore, DHA induced caspase-dependent apoptosis in HCC SK-Hep-1 cells through proteasome-dependent degradation of specificity protein 1 (Sp1) [22]. Several signaling pathways were found to be significantly associated with DHA-induced apoptosis. DHA induced the apoptosis of colon cancer cells by targeting janus kinase 2 (JAK2)/signal transducer and activator of transcription 3 (STAT3) signaling [23]. Furthermore, 
NF-kB signaling pathway was also shown to play an important role in the process of DHA-induced apoptosis [24-26]. Another study reported that DHA induced apoptosis in BGC823 gastric cancer cells by c-Jun $\mathrm{NH}_{2}$-terminal kinases (JNK1/2) and p38 mitogen-activated protein kinase (p38 MAPK) signaling pathways [27]. In addition, the activation of $\mathrm{Ca}^{2+}$ and p38 was also observed in DHA-induced apoptosis of PC14 lung cancer cells [28] (Figure 3). More importantly, DHA was also shown to be able to induce apoptosis in ovarian cancer cells, and compared with a series of ARTs, DHA had the strongest effect [29].

Some molecular targets of DHA-induced apoptosis of tumor cells were also found. Maria Lucibello et al. found that DHA induced apoptosis by targeting a phosphorylated form of translationally controlled tumor protein (TCTP). Subsequently, the clinical data showed nuclear phosphorylation of TCTP was increased in primary breast cancer tissues compared with that seen in normal tissues, which was accompanied by higher histological grade and increased Ki-67 expression. These results suggested that phosphorylated TCTP might be a potential target of DHA in the treatment of advanced breast cancer [30]. Ge Xu et al. revealed that the down-regulation of heat-shock protein 70 (HSP70) might participate in the apoptosis of PC3 prostate cancer cells induced by DHA via proteomics analysis [31]. In addition, Jin Kong et al. demonstrated through experiments that DHA could inhibit the expression of HSP70 and induce apoptosis in PC3 cells [32]. Furthermore, DHA inhibited the growth of colon tumor by inducing apoptosis and increasing the expression of peroxisome proliferator-activated receptor $\gamma($ PPAR $\gamma)$ [33].

Metabolic pathways are also closely related to apoptosis. DHA was shown to inhibit the activity of glucose transporter-1 (GLUT1) and glycolytic pathway by inhibiting phosphatidyl-inositol-3-kinase (PI3K)/AKT pathway and downregulating the expression of hypoxia inducible factor-1a (HIF-1a), thereby inducing LNCaP cell apoptosis [34]. Pyruvate kinase M2 (PKM2) is a key regulator of glycolysis, and a study by Shumin Li et al. reported that PKM2 expression was higher in esophageal squamous cell carcinoma than in normal tissues. Interestingly, DHA could inhibit the expression of PKM2 as well as inhibit lactic acid production and glucose uptake, thereby promoting the apoptosis of esophageal cancer cells [35]. Furthermore, DHA induced caspaseindependent apoptosis-like cell death in Colo205, HCT15 and HCT116 colorectal cancer cells in the absence of oxygen. Notably, normoxic and hypoxic conditions did not make a significant difference in this effect. Thus, the results demonstrated that DHA showed significant cytotoxicity in severe hypoxia and normoxic environments, which provided a new perspective for the treatment of tumor cells in hypoxia [36]. The above results indicated that DHA could induce apoptosis of tumor cells by regulating the metabolic process.

\section{Inhibition of metastasis}

Tumor metastasis refers to the process by which cancer cells escape from the primary tumor and break down the extracellular matrix, eventually reaching other sites for further growth [37]. Despite the progress that has been made in the treatment of cancer, there have been no substantial reductions in the high mortality rate in the past few years, primarily because of the metastasis of cancer cells $[38,39]$. In clinical treatment, tumor metastasis will greatly increase the risk of postoperative recurrence and shorten the survival rate of patients. Therefore, effective inhibition of tumor metastasis is the top priority of tumor therapy.

There are many key molecules involved in the adhesion, migration and invasion of cancer cells. Epithelial-mesenchymal transition (EMT) is the process by which epithelial cells transform into mesenchymal cells and then acquire the ability of migration and invasion. Moreover, matrix metalloproteinases (MMPs) can degrade the extracellular matrix, which is beneficial to tumor migration and invasion. DHA inhibited the migration and invasion of canine mammary cancer cells by regulating the EMT-related genes (Slug, ZEB1, ZEB2 and Twist) [40]. In addition, DHA was shown to inhibit the proliferation and EMT of SGC7901 gastric cancer cells and downregulated the expression of Snail and PI3K/AKT signaling pathway, thereby inhibiting metastasis [41]. Yuyuan Yao et al. found that DHA suppressed the activation of cancer-associated fibroblasts (CAFs) and mouse cancer-associated fibroblasts (L-929-CAFs) by inhibiting transforming growth factor- $\beta$ (TGF- $\beta$ signaling and reducing the interaction between tumor and tumor microenvironment. Therefore, DHA inactivated CAFs and inhibited cancer metastasis [42]. By using an ovarian HO8910PM xenograft tumor model, DHA was shown to inhibit tumor metastasis in vivo. Interestingly, DHA inhibited the development of ovarian cancer by downregulating phosphorylated focal adhesion kinase (pFAK), MMP-2, von willebrand factor (vWF) and macrophage infiltration [43]. A recent study showed that DHA inhibited HNSCC cell migration and invasion by blocking the phosphorylation of STAT3 and polarization of M2 macrophages [44]. Urokinase-type plasminogen 
activator (uPA) is considered a marker of poor prognosis, and the expression level of uPA is positively correlated with relapse risk in breast cancer patients [39]. Interestingly, we found that DHA could inhibit the growth and migration of breast cancer cells by inhibiting the expression of uPA [45].

Likewise, some signaling pathways were identified in the process of tumor metastasis inhibited by DHA. Yunli Tong et al. observed that DHA could inhibit cell proliferation, migration, invasion, cancer stem cells and EMT of non-small cell lung cancer (NSCLC). In these processes, the suppression of Wnt/ $\beta$-catenin signaling pathway played an important role [46]. Another study showed that DHA was able to inhibit the migration and invasion of NSCLC cells even at low concentrations. Besides, blocking NF-kB signaling could largely abolish the inhibition of GLUT1 transport to the plasma membrane by DHA [47]. DHA also inhibited cell viability, migration, invasion and induced apoptosis of epithelial ovarian cancer (EOC) cells via inhibiting the hedgehog signaling pathway [48] (Figure 3). A recent study identified that DHA inhibited the growth and invasion of gastric cancer cells and confirmed that Cyclin D1-CDK4-Rb signaling played an important role in this process [49]. In addition, DHA could inhibit the proliferation, migration and invasion of MDA-MB-231 breast cancer cells with the AKT/steroid receptor coactivator (SRC) signaling pathway involved, thereby inhibiting breast tumor-induced osteolysis [50]. Interestingly, Juliano D. Paccez et al. identified that DHA acted as an Axl inhibitor in prostate cancer, blocking the expression of Axl through the miR-34a/miR-7/JARID2 pathway, thereby inhibiting the proliferation, migration and invasion of prostate cancer cells. These results provided a new molecular basis for the treatment of metastatic prostate cancer [51].

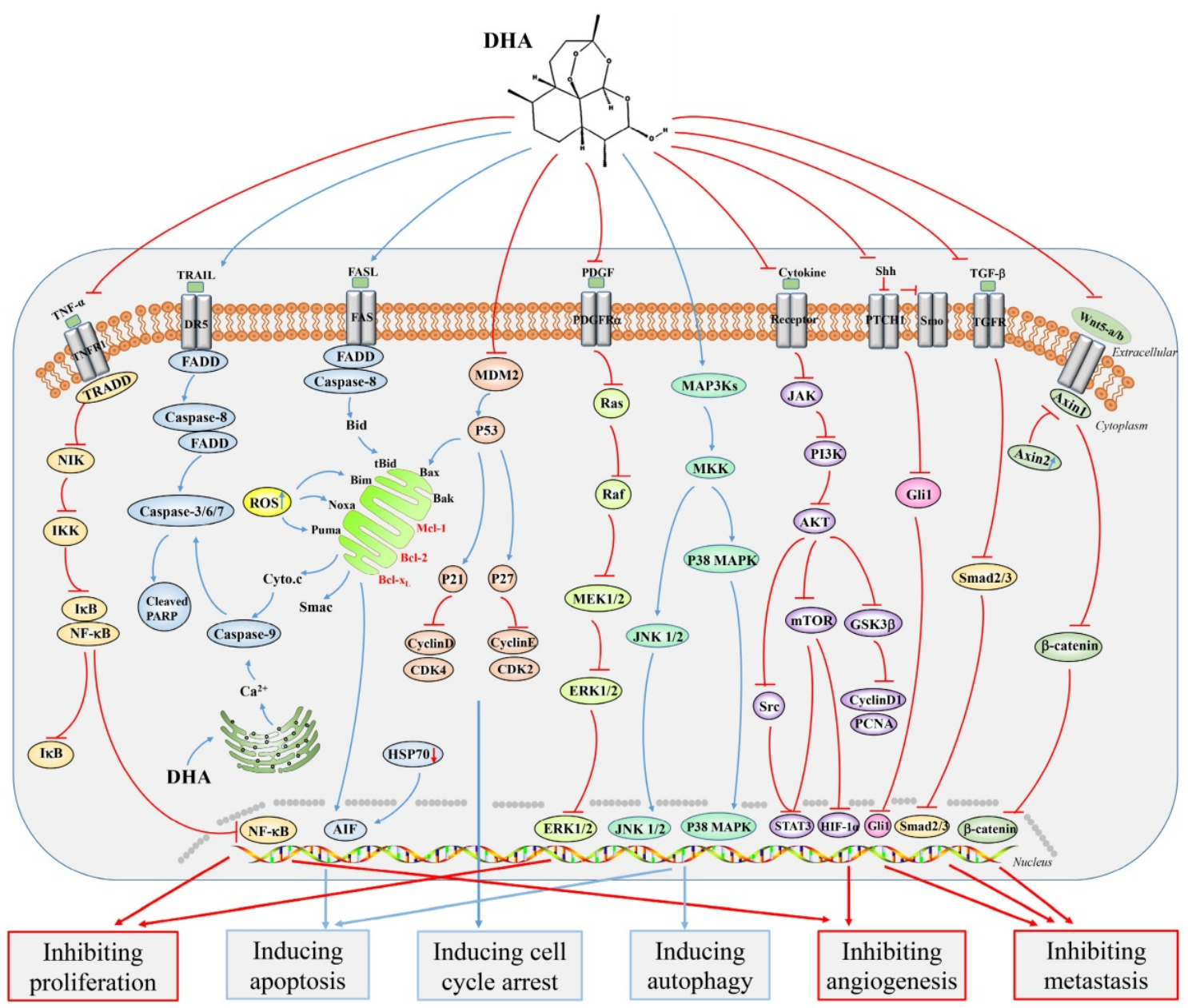

Figure 3. Major signaling pathways involved in the anticancer effects of dihydroartemisinin. Dihydroartemisinin can inhibit the NF-KB, TGF- $\beta$, hedgehog, PI3K/AKT/HIF-1K, JAK2/STAT3, Wnt/ $\beta$-catenin, AKT/GSK-3ß/Cyclin D1, and AKT/mTOR/STAT3 signaling pathways. In addition, dihydroartemisinin can activate the JNK1/2, P38 MAPK, death receptor-mediated and mitochondrion-mediated caspase-dependent apoptotic signaling pathways. Red curves indicate inhibition and blue arrows indicate activation of these processes. 


\section{Inhibition of angiogenesis}

In the growth of solid tumor, if there is not enough supply of oxygen and nutrients, the growth of tumor will be limited to about 1-2 $\mathrm{mm}^{3}$ [52]. Therefore, the continued growth and metastasis of tumor must depend on the angiogenesis. Inhibition of tumor angiogenesis has become an important anticancer therapy. DHA has been proved to have a significant effect on angiogenic activity. DHA significantly inhibited the proliferation, migration and tube formation of human umbilical vein endothelial cells (HUVECs) [53]. Shuangjia Wang et al. found that DHA inhibited angiogenesis and tumor growth in pancreatic cancer cells, reduced NF-KB DNA binding activity, and downregulated the pro-angiogenic gene in downstream [54]. Moreover, another study found that DHA-induced microRNA-mRNA regulatory networks promoted apoptosis and inhibited angiogenesis in pancreatic cancer cells, which were consistent with experiments results in vivo [55]. Another study showed that DHA induced autophagy of HUVECs by inhibiting AKT/mTOR signaling [56]. The study found that DHA enhanced vascular endothelial growth factor receptor 1 (VEGFR1) expression through upregulation of ETS-1. Therefore, the authors hypothesized that DHA's anti-angiogenic effect might be due to the inhibition of VEGFR2-mediated angiogenesis [57].

\section{Improvement of immunity}

DHA has made great progress in the treatment of systemic lupus erythematosus mainly because of the inhibition of B lymphocytes. This reveals the potential role of DHA in immunotherapy. Shokoofe Noori et al. demonstrated that in a sheep red blood cell (sRBC) xenograft model, delayed-type hypersensitivity (DTH) was significantly increased in the treatment of DHA compared with that observed with the control regimen treatment. Besides, in a spontaneous mouse mammary tumor (SMMT) xenograft model, the level of IFN- $\gamma$ was increased, while those of IL-4 and splenic CD4 ${ }^{+} \mathrm{CD} 25^{+} \mathrm{Foxp}^{+}$ regulatory $\mathrm{T}$ lymphocytes were significantly reduced with the DHA treatment [58]. Zhonghai Zhou et al. studied the effect of DHA on $\gamma \delta$ T cells (a type of immune cells). The results revealed that an appropriate concentration of DHA was beneficial to the amplification of $\gamma \delta$ T cells. Notably, DHA could promote the killing effect on pancreatic cancer cells by enhancing the proliferation of $\gamma \delta \mathrm{T}$ cells. In this process, the upregulation of some cytotoxic effector molecules (such as perforin and granzyme B) and IFN- $\gamma$ would help to the killing efficacy on pancreatic cancer cells, which may be vital mechanisms for DHA to enhance the anti-tumor effect of pancreatic cancer cells [59]. A study of DHA in melanoma showed that DHA induced the proliferation of IFN $-\gamma^{+} \mathrm{CD} 8^{+} \mathrm{T}$ cells in tumor microenvironment and mouse spleens, while the number of $\mathrm{CD}_{4}{ }^{+} \mathrm{CD} 25^{+} \mathrm{Foxp} 3^{+} \mathrm{T}$ cells and IL- $10^{+} \mathrm{CD} 4{ }^{+} \mathrm{CD} 25^{+} \mathrm{T}$ cells returned to normal, thus enhancing the anti-tumor immunity of mice [60].

\section{Induction of autophagy}

Autophagy is a kind of self-degradation process in the normal life of cells. Specifically, it means that some intracellular components of cell are wrapped in the membrane to form a cystic structure and transport to lysosome for degradation. There is an increasing evidence showed that the autophagy-mediated triggering of type II programmed cell death remarkably improved the therapeutic effects of DHA towards xenogeneic breast cancer [61]. Boning Li et al. studied new targets for DHA in EOC cells and observed that DHA induced autophagy, while autophagy inhibitors (chloroquine and bafilomycin A) were able to reverse the cell growth inhibition and cycle arrest induced by DHA [62]. Xinli Shi et al. described the relationship between inflammatory body and autophagy induced by DHA in HCC. They revealed that DHA promoted the AIM2/caspase-1 inflammasome, induced nuclear and mitochondrial DNA damage and ultimately promoted autophagy in HepG2215 cells [63]. Cells treated with DHA exhibited the trait of autophagy with JNK pathway activated and Beclin 1 expression upregulated. Specifically, after treatment with DHA, the produced ROS led to JNK activation [64]. Another study demonstrated that DHA inhibited the migration of esophageal cancer cells by inducing autophagy [65]. These studies suggested that autophagy induction might be the key to the anticancer effect of DHA.

In addition, some clinical drugs can also kill tumor cells together with DHA by enhancing the level of autophagy. Rapamycin is an antibiotic that can induce autophagy in various cell types. One present study revealed that rapamycin significantly promoted the apoptosis of breast cancer cells induced by DHA, but this effect will be reduced following Atg7 knockdown. Meanwhile, rapamycin could promote the level of death-associated protein kinase (DAPK) expression by increasing autophagy-related 7 (Atg7) expression, and then together with DHA to enhance breast cancer cell apoptosis. Hence, this combined anticancer effect depended on the induction of autophagy [66].

\section{Induction of ER stress}

$E R$ is an organelle responsible for protein synthesis, folding and secretion in eukaryotic cells. However, ER homeostasis imbalance can lead to ER 
stress, and then affect the normal life of cells. Tumor cells contain more iron transporter receptors than normal cells, and iron can combine with the metabolites of DHA to form free radicals that lead to cytotoxic effects. Therefore, it is generally believed that excessive free iron ions in tumor cells are key factors for the ability of DHA to selectively kill tumor cells. Glucose regulatory protein 78 (GRP78, an ER stress-related molecule) was upregulated after DHA treatment. Further studies found that DHA increased the expression of GRP78 and DNA damage-inducing gene 153 (GADD153, another ER stress-related molecule). However, when HCT116 colon cancer cells were pre-treated with the iron chelator deferoxamine mesylate salt (DFO), the induction of GRP78 and GADD153 would be abolished. Thus, these results demonstrated that DHA-induced ER stress required iron [67]. Controversially, another recent study showed that DHA dimer NSC735847 was cytotoxic for colorectal cancer. However, its induction of ER stress required the presence of heme, not the iron [68]. This might be due to some chemical changes in DHA dimers compared with DHA monomers, so the mechanism of inducing ER stress might be changed.

\section{New methods to improve the clinical efficacy of DHA}

DHA is a sesquiterpene lactone compound containing peroxide bridges. The unique structure of DHA results in poor water solubility and bioavailability, and multiple injections are often required to achieve the desired therapeutic effect, which greatly hinders the clinical application of DHA in cancer [69]. To overcome this obstacle, there are many new approaches for DHA usage, such as the use of new drug carriers and polymers, new drug delivery systems and combination therapies. Here, we make a systematic summary of the reported improvements in the use of DHA.

\section{Drug carrier and polymer}

Encapsulating DHA in carrier materials or designing it as a polymer may greatly improve the water solubility and bioavailability. Qian Sun et al. encapsulated DHA in gelatine (GEL) or hyaluronic acid (HA) nanoparticles using an electrostatic field system. The results revealed that DHA nanoaggregates exhibited higher anti-proliferative activity and bioavailability than DHA alone in A549 lung cancer cells. The reason may be that the hydrophilic GEL or HA nanoparticles have higher water dispersion after aggregation [70]. Similarly, Lin Dai et al. designed a novel polymer-drug conjugate, multi-arm polyethylene glycol-DHA (PEG-DHA). They connected DHA with multi-arm polyethylene glycol. The PEG-DHA conjugate showed a moderate drug loading value, better water solubility (82-163-fold that of DHA), and a better anticancer effect in vitro. Subsequently, tumor xenograft assay demonstrated PEG-DHA had stronger efficacy on inhibiting tumor growth than native DHA in NSCLC. Owing to the excellent anticancer efficacy, high drug loading capacity, suitable molecular weight and minimal inherent impurities during conversion, 8armPEG40K-DHA was expected to undergo further clinical development for the treatment against NSCLC [71]. Yingjie $\mathrm{Hu}$ et al. developed a combination therapy strategy by constructing nanostructured DHA and epirubicin liposomes. In their study, the results showed that DHA improved the inhibitory effect of epirubicin towards breast cancer cells in vitro and in vivo, and this combination induced type I and type II programmed death of breast cancer cells. Besides, the nanostructured DHA plus epirubicin liposomes lengthened the drug's circulation and promoted its accumulation in breast cancer tissues [72]. There was a study explored the role of $\mathrm{R}_{8}$-modified epirubicin-dihydroartemisinin liposomes that targeted NSCLC cells. In this context, the liposomes disrupted vasculogenic mimicry (VM) channels and inhibited tumor metastasis. This strategy showed significant anti-tumor efficacy owing to increased selective accumulation of chemotherapeutic drugs at the tumor [73]. Another study found that octreotide (OCT)-modified daunorubicin plus DHA liposomes had stronger anti-tumor effects than either treatment alone and could inhibit breast cancer invasion [74], which may provide new strategies for the treatment of metastasis breast cancer.

\section{Drug delivery system}

The endoperoxide bridge structure of DHA is important for its antimalarial and anticancer activities, and DHA is thought to exert its cytotoxic effect through Fe (II)-mediated endoperoxide cleavage [75]. Cancer cells often overexpress transferrin receptor (TfRs) to ingest iron, while TfR levels are almost undetectable in most normal cells [76]. Therefore, Ikuhiko Nakase et al. made a series of artemisinin-tagged transferrin (ART-Tf) conjugates, which retained the activity of artemisinin. It was demonstrated that ART-Tf conjugates played a cytotoxic role through the mitochondrial pathway of apoptosis in prostate cancer cells [77]. Thus, TfRs may be a biomarker for the selective delivery of anticancer drugs. Interestingly, Narendra et al. adopted a treatment method of "full transferrin+dihydroartemisinin". This combination used an original approach in the treatment of breast cancer, where oral 
iron salts such as ferrous sulfate or ferrous citrate would increase the iron content in breast tumor, making cells more susceptible to cytotoxic effects. Thus, with the use of appropriate dosing regimens, oral or gastrointestinal administration of artemisinin analogues plus ferrous salts may be effective anti-breast cancer therapies [78]. Further, a new study describes a hydrogel tumor treatment system that works in conjunction with DHA. Authors designed a hydrogel containing $\mathrm{FeCl}$, traditional Chinese ink and agarose hydrogel. Heat caused the hydrogel to hydrolyse reversibly, and the iron then diffused from the hydrogel to the tumor microenvironment, where it was reduced to iron, broke the inner peroxides bridge of DHA and released free radicals that showed a powerful anticancer effect. Experiments have also shown that DHA-Fe has significant efficacy in chemodynamic therapy (CDT) and photodynamic therapy (PDT) [79].

\section{Combination medication}

Combination of drugs is a common clinical cancer treatment method. The multi-drug resistance of tumor cells and adverse reactions to chemotherapy drugs often lead to the failure [80]. Remarkably, the combination of drugs would enhance the anti-tumor effect of drugs and even reverse some known drug resistance [81]. Current research showed that DHA had a stronger anti-tumor effect in the synergy with a variety of chemotherapeutic drugs, and DHA could reverse the drug resistance of certain cancer cell lines. Moreover, some new technologies have been used in cancer treatment combined with DHA.

\section{Improvement of anticancer effect}

DHA in combination with some chemotherapeutic drugs can greatly enhance the anticancer effect. The combination of DHA and carboplatin (CBP) showed great inhibition on the growth of ovarian cancer cells as well as in ovarian A2780 and OVCAR-3 xenograft tumor models, which might be achieved through death receptors and the mitochondria-mediated caspase-dependent apoptosis pathway [82]. Furthermore, Huijun Zhou et al. studied the effect of DHA in combination with cyclophosphamide (CTX) or cisplatin. They observed that DHA induced apoptosis in Lewis lung carcinoma (LLC) cells and affected the expression of VEGF receptor KDR/flk-1. Furthermore, in tumor xenograft models, compared with the drug alone, this combination showed stronger anti-growth and anti-metastasis effects. This study revealed the potential clinical significance of treating LLC using a combination DHA and chemotherapeutics (such as CTX and cisplatin [83]. Gefitinib is a commonly used drug for the treatment of patients with local or metastatic NSCLC. Notably, DHA enhanced gefitinib-induced inhibition of NCI-H1975 lung cancer cells in migration and invasion via AKT/mammalian target of rapamycin (mTOR)/STAT3 signaling pathway, and co-administration of DHA and gefitinib induced cell cycle arrest in the G2/M phase [84] (Figure 3). Onconase (Onc) is a ribonuclease from leopard frog oocytes or early embryos and is used to treat malignant mesothelioma in clinical. A further study found that Onc combined with DHA had a strong antiangiogenic efficacy with low toxicity and immunogenicity, and this combination can serve as a novel regimen for NSCLC [85]. DHA also cooperated with trastuzumab for the treatment of HER2/neu positive breast cancer to induce apoptosis of tumor cells [30]. Notably, one study showed that DHA synergized with docetaxel, resulting in an enhanced anti-tumor efficacy and increased overall survival of xenografted mice [51]. The combination of DHA and curcumin (Cur) exhibited synergistic anti-tumor effects on SKOV3 ovarian cells in vitro and in vivo. Furthermore, this combination could effectively weaken the expression of the oncogene midkine (MK) and upregulate miR-124 expression [86]. DHA could inhibit the growth of HCC cells (HepG2, Hep3B, BEL-7404 and Huh-7) and pancreatic cancer cells (BxPC-3 and PANC-1). DHA combined with gemcitabine induced cell cycle arrest in G1 phase and promoted cell apoptosis. Specifically, DHA inhibited gemcitabine-induced NF-kB activation. Further, xenograft tumors in vivo also confirmed these results $[87,88]$.

Doxorubicin (DOX) is a commonly used anti-tumor drug, which can exert a strong cytotoxic effect by inhibiting the synthesis of DNA and RNA of cancer cells. DHA and DOX had been found to work together to inhibit the proliferation of MCF-7 breast cancer cells. Compared with monotherapy, the combined therapy significantly reduced mitochondrial membrane potential, activated the caspase cascade and finally induced apoptosis [89]. Similarly, Maria Lucibello et al. also demonstrated the synergy between DHA and DOX. DHA could significantly enhance the anti-tumor effect of DOX on triple-negative breast cancer cells, thus leading to an increased induction of apoptosis [30]. Furthermore, the combination of DHA and DOX was shown to promote apoptosis at optimal concentrations of 10 $\mu \mathrm{g} / \mathrm{ml}$ of DHA and $10 \mu \mathrm{g} / \mathrm{ml}$ of DOX. The mouse HeLa tumor model showed that this combination significantly inhibited tumor growth without significant toxicity [90].

Remarkably, DHA in combination with several 
inhibitors has also shown a significant anti-tumor efficacy. DHA could directly target platelet-derived growth factor receptor-alpha (PDGFR $\alpha$ ) to inhibit the growth and metastasis of ovarian cancer cells. When DHA was used in combination with PDGFR $\alpha$ inhibitors (sunitinib and sorafenib), it could sensitize ovarian cancer cells to PDGFR inhibitors and achieved effective therapeutic efficacy [91]. Moreover, DHA combined with 2DG (a glycolysis inhibitor) synergistically induced apoptosis through both exogenous and endogenous apoptotic pathways [92]. Chris Zhiyi Zhang et al. demonstrated that histone deacetylase inhibitors (HDACis) enhanced the anti-tumor effect of DHA by inducing apoptosis. For instance, the combination therapy reduced mitochondrial membrane potential compared with DHA treatment alone. In addition, DHA was observed to induce apoptosis, increase the expression of p53 and Bak, decrease the expression of Mcl-1 and pERK, and activate caspase 3 and poly ADP-ribose polymerase (PARP). The results demonstrated the synergistic effects of DHA and HDACi in HCC [93]. Liping $\mathrm{Wu}$ et al. identified the synergistic anticancer effect with farnesylthiosalicylic acid (FTS, a RAS inhibitor) and DHA for the first time. FTS could sensitize HCC cells to DHA treatment by enhancing the intrinsic and extrinsic apoptotic pathways. Thus, this study gave a strategy for the clinical application of ARTs and FTS in the treatment of HCC [94]. NSCLC cells typically harbour epidermal growth factor receptor (EGFR) or RAS mutations [95]. Xiaohui Yan et al. found that DHA combined with ABT-263 (a Bcl-2 family inhibitor) could induce apoptosis of NSCLC harbouring EGFR or RAS mutations. Specifically, DHA effectively inhibited the phosphorylation of STAT3, and STAT3 inactivation resulted in the down-regulation of Mcl-1 and survivin, thereby enhancing the cytotoxicity induced by ABT-263. These data provided a new treatment strategy for treating NSCLC with EGFR or RAS mutations [96]. Moreover, data presented by Qin He et al. indicated that DHA inhibited PI3K/AKT and extracellular signal-regulated kinase (ERK) pathways and activated the exogenous and endogenous cell death signals in prostate cancer cells. The combination treatment of DHA and tumor necrosis factor-related apoptosis inducing ligand (TRAIL) greatly improved cell killing. In summary, the authors propose new clinical approaches for prostate cancer therapies, namely, treatment with DHA alone or in combination with TRAIL [97].

Interestingly, DHA in combination with some new therapies may also promote anti-tumor effects. PDT is a photodynamic reaction between a photosensitizer and light of the corresponding wavelength, which results in the production of singlet oxygen, thereby killing tumor cells. PDT has been widely used in the treatment of esophageal cancer, and can significantly relieve esophageal obstruction and prolong survival in patients. However, PDT-induced NF-kB activation may lead to a decline in the efficacy of PDT therapy $[98,99]$. Yanjing Li et al. showed that DHA enhanced PDT-induced cell growth inhibition and apoptosis [100], and an additional investigation further reported that DHA increased the sensitivity of esophageal cancer cells to PDT by inhibiting the NF-kB/HIF-1 $\alpha$ /VEGF pathway [101]. Furthermore, CDT can also be combined with DHA. In a recent study, DHA was added to magnetic nanoparticles (MNP), and the MNP-DHA has shown an effect in the treatment of intractable breast cancer. These studies showed that blank MNP had almost no cytotoxicity, whereas MNP-DHA had a significant inhibitory effect on two invasive breast cancer cell lines (MDA-MB-231 and MDA-MB-453 cells). Under the acidic condition in the tumor microenvironment, MNP could produce ferrous ions and catalyse DHA to produce a large amount of ROS, thereby leading to cell death and greatly improving the therapeutic effect of CDT [102].

\section{Reversal of resistance}

Cisplatin is one of the most commonly used chemotherapy drugs. Compared with that observed in control SKOV3 cells, mTOR phosphorylation was shown to be abnormally activated in cisplatinresistant ovarian cancer cells (SKOV3/DDP) after cisplatin monotherapy. Further, the authors found that DHA promoted autophagy and apoptosis in SKOV3/DDP cells, and the inhibition of mTOR signaling pathway was involved. Notably, the inhibition of mTOR signaling pathway was involved in this process. Therefore, it was concluded that the killing effect of DHA towards SKOV3/DDP cells was achieved by inhibiting cisplatin-induced mTOR activation [103]. Arsenic trioxide $\left(\mathrm{As}_{2} \mathrm{O}_{3}, \mathrm{ATO}\right)$ is a curative anticancer drug used to treat acute promyelocytic leukaemia and some specific cancers [104]. However, lung cancer cells were recently observed to be resistant to ATO. Hongyu Chen et al. investigated the possibility of combining DHA with ATO. They found this combination synergistically promoted the apoptosis of A549 lung cancer cells by increasing the levels of ROS and DNA damage. More importantly, the combination therapy did not have significant adverse effects on normal human bronchial epithelial cells [105]. Apo2 ligand (Apo2L)/TRAIL is considered as a prospective anticancer agent, but the chemical resistance affects its efficacy. It was reported that combination therapy 
with DHA and Apo2L/TRAIL promoted the induction of apoptosis in BxPC-3 and PANC-1 pancreatic cancer cells compared to monotherapy. In this study, DHA induced DR5 and regulated apoptosis-associated proteins to mediate cell apoptosis by producing ROS [106].

\section{Preliminary studies of clinical anticancer effects}

\section{Preclinical trials}

In addition to numerous basic experimental studies on the anticancer effects of DHA, there are also some preliminary researches on its pharmacodynamics and pharmacokinetics.

Since the binding affinity of DHA to serum proteins can affect the effectiveness of the drug, one study examined the binding of DHA to serum albumin under near-physiological conditions. The data showed changes in enthalpy and entropy, where hydrophobic force was the most important contributor. Interestingly, molecular docking studies revealed small changes in the chemical structure of a drug would significantly affect the binding of a drug to its target protein [107].

The cytochrome P450 (CYP) enzyme system can greatly influence the oxidative metabolism of drugs, and the modification of this system is an important factor influencing drug-drug interactions (DDIs). The effects of ARTs on seven major human liver CYP isoforms (CYP1A2, CYP2A6, CYP2B6, CYP2C9, CYP2C19, CYP2D6 and CYP3A4) were evaluated and DDI risk was predicted in vivo. In conclusion, DHA was shown to inhibit the enzyme activity of CYPs, mainly through mixed inhibition [108]. The inhibition of CYP enzymes in the body may result in an increased drug plasma concentration, thereby leading to the occurrence of adverse reactions.

Animal models (such as cats and dogs) can also be used to study preclinical problems prior to clinical studies. A large clinical study of more than 15,000 malaria patients found no significant toxicity of DHA $[109,110]$. However, preclinical toxicity studies in healthy experimental dogs using artemisinin derivatives showed neurotoxicity [111]. Similarly, canines with spontaneous tumors showed good tolerance to artemisinin but had anorexia and low bioavailability after oral administration [112]. Taken together, these results indicate that ARTs may have potential toxicity.

\section{Clinical trials}

Previous studies have confirmed that DHA is cytotoxic to cervical cancer cells. Jansen et al. further investigated the clinical effect and safety of oral
Artenimol-R (the succinate ester of DHA) in patients with advanced cervical cancer. Ten patients were treated with DHA for 28 days, with follow-up monitoring of clinical symptoms, vaginal discharge, pain and adverse reactions. Furthermore, the expressions of tumor-related markers in the biopsy samples were analysed by immunohistochemistry. Overall, the results showed that DHA treatment induced clinical symptom relief and the median time to symptom disappearance decreased compared with that observed in the control group. Grade 3 or 4 adverse events did not happen. Besides, the expressions of some proliferation markers such as p53, EGFR and Ki-67 were reduced; the number of blood vessels stained with CD31 was decreased; and the expression of transferrin receptor protein 1 (CD71) was increased. Thus, this study provided a basis that DHA could improve the clinical symptoms of advanced cervical cancer patients and it was well tolerated [113]. However, it is necessary to conduct further survival trials in patients with advanced cervical cancer.

We have reviewed the clinical trial websites of various countries worldwide. Thus far, in addition to anti-malaria, we have identified only three clinical trials of DHA in Clinicaltrials.gov and Chinadrugtrials.org.cn. There is only one clinical trial on anti-tumor effect of DHA named Icotinib Combined With DHA Therapy in Patients With Advanced NSCLC. This phase II clinical study explored the anti-tumor effect of the combination of DHA and icotinib on EGFR-positive NSCLC patients, with identification number NCT03402464. The method of medication is as follows: On day 1-3, oral DHA was given at $20 \mathrm{mg}$ per day, the dose of DHA is increased to $40 \mathrm{mg}$ daily on day 4 to 6 , and $80 \mathrm{mg}$ twice daily until disease progressed or intolerable toxicity. This clinical trial is still ongoing. The other two clinical trials are phase II clinical trials for the treatment of systemic lupus erythematosus in China, with identification numbers CTR20171440 and NCT03396393, respectively.

Due to the limited anti-tumor clinical trials of DHA, we also reviewed some clinical trials of ARTs, and there have been some anti-tumor clinical trials on artesunate. The treatment of metastatic breast cancer with artesunate was proved to be well tolerated by patients [114]. Moreover, artesunate showed a good therapeutic effect on colorectal cancer [115]. The pharmacokinetic analysis of oral artesunate demonstrated that the apparent clearance rate of DHA (the active metabolite of artesunate) increased with time, and the drug could be stably metabolized [116]. Remarkably, treatment of metastatic breast cancer with artesunate showed ototoxicity [117], 
which also needs to be noticed in clinical trials of DHA.

Given the results discussed above, artesunate has been proven to have significant anti-tumor effects in clinical trials, and it can be speculated that DHA (its active metabolite) has great potential in cancer treatment. However, the anti-tumor research of DHA remains nascent and incomplete. Hence, we need to conduct further research to develop chronic toxicology and drug interaction studies of DHA, as well as more and larger clinical trials. These studies will lay the foundation for the clinical use of DHA as an anticancer drug and provide a more convincing evidence for the applicability of DHA in clinical oncology.

\section{Current developments and limitations of DHA}

DHA is a commonly used antimalarial drug with anticancer effects, and it is receiving more and more attention. In the research and development of drugs, exploring new indications using old drugs will greatly shorten the time of drug development. As an antimalarial drug, the dose for adults is $120 \mathrm{mg}$ on the first day, and $60 \mathrm{mg}$ per day thereafter for 5-7 days. Within the normal dosage, only a small number of patients will experience a mild transient reduction in reticulocytes, and there is no serious adverse reaction. Therefore, the known drug safety makes the development of new indications for DHA convenient and efficient.

In the past two decades, numerous reports have emerged on the anti-tumor activity of DHA. These findings strongly supported that DHA had effective anticancer roles, which indicated that DHA could be a potential candidate for cancer treatment. Table 1 lists the range of effective doses and effects of DHA used in various cancer types, which provides a comparison and reference of DHA in various disease models.

Recently, cancer treatment has focused on individualized medications and combined drug therapy to improve drug sensitivity and therapeutic effects [118]. According to the research above, DHA combined with a variety of existing chemotherapy drugs have demonstrated significant anti-tumor effects, which could be helpful to solve current clinical drug resistance of tumor. This review summarizes the combination of DHA and chemotherapy drugs, and shows the effective doses and effects of DHA in vitro and in vivo, thereby providing a reference for future combined applications of clinical drugs (Table 2).

However, there are still some limitations regarding anticancer studies of DHA. Firstly, the anticancer mechanism of DHA is still unclear and requires further research. Secondly, the metabolites and metabolic pathways of DHA in vivo have not been clearly studied, which will help us better understand the mechanism of DHA in vivo. Thirdly, the neurotoxicity and ototoxicity observed in preclinical trials cannot be ignored, thus, new drug dosages or improved drug structures should be developed in the future to avoid DHA-mediated toxicity and side effects. Furthermore, since DHA has limited clinical trials in tumor, its clinical anticancer efficacy and drug resistance remain unknown.

Table 1. Summary of the anticancer data about effective dose ranges and effects of dihydroartemisinin in vitro and in vivo

\begin{tabular}{|c|c|c|c|c|}
\hline Cancer type & Model type & Effective doses & Main effects & Reference \\
\hline \multirow[t]{8}{*}{$\begin{array}{l}\text { Lung } \\
\text { cancer }\end{array}$} & A549 cell & $10-30 \mu \mathrm{M}$ & $\begin{array}{l}\text { Inhibited cell proliferation } \\
\text { Induced cell cycle arrest } \\
\text { Upregulated the ratio of Bax/Bcl-2 } \\
\text { Activated of caspase } 3 \text { and cytochrome c } \\
\text { Inhibited the AKT/GSK3 } \beta \text { /cyclin D1 pathway }\end{array}$ & [12] \\
\hline & PC-14 cell & $18 \mu \mathrm{M}$ & $\begin{array}{l}\text { Inhibited cell proliferation } \\
\text { Induced apoptosis } \\
\text { Induced } \mathrm{Ca}^{2+} \text { increasing } \\
\text { Increased } \mathrm{p} 38 \text { phosphorylation }\end{array}$ & [28] \\
\hline & A549, H1299 cells & 7.5-30 $\mu \mathrm{M}$ & $\begin{array}{l}\text { Inhibited cell proliferation } \\
\text { Induced G1 cell cycle arrest by inhibiting cyclin D1 } \\
\text { Inhibited cell migration and invasion } \\
\text { Suppressed EMT } \\
\text { Inhibited Wnt/ } \beta \text {-catenin signaling pathway }\end{array}$ & [46] \\
\hline & A549 tumor xenograft model & $\begin{array}{l}60 \mathrm{mg} / \mathrm{kg} / 5 \text { times/week for } 4 \text { weeks } \\
\text { (i.g.) }\end{array}$ & $\begin{array}{l}\text { Inhibited tumor growth } \\
\text { Downregulated Wnt5-a/b, LRP6, and Dvl2 } \\
\text { Upregulated NKD2 and Axin2 }\end{array}$ & [46] \\
\hline & A549, H1975 cells & $7.5-30 \mu \mathrm{M}$ & $\begin{array}{l}\text { Inhibited cell viability, migration and invasion } \\
\text { Decreased ATP production, glucose uptake and lactate levels } \\
\text { Inhibited transcriptional activity of the NF-kB } \\
\text { Inhibited plasma membrane location of Glut } 1\end{array}$ & [47] \\
\hline & A549 tumor xenograft model & 50 or $100 \mathrm{mg} / \mathrm{kg} /$ day for 28 days & Inhibited tumor metastasis & [47] \\
\hline & A549 cell & $\begin{array}{l}\text { GEL/DHA and HA/DHA aggregates } \\
10-40 \mu \mathrm{g} / \mathrm{mL}\end{array}$ & $\begin{array}{l}\text { Inhibited cell proliferation } \\
\text { Induced apoptosis }\end{array}$ & [70] \\
\hline & LLC tumor xenograft model & DHA or PEG-DHA (i.v.) & Inhibited tumor growth & [71] \\
\hline
\end{tabular}




\begin{tabular}{|c|c|c|c|c|}
\hline & & $\begin{array}{l}\text { a. } 50 \mathrm{mg} / \mathrm{kg} \text { single dose } \\
\text { b. } 10 \mathrm{mg} / \mathrm{kg} \text {, every } 2 \text { days, } \mathrm{q} 2 \mathrm{~d} \times 5\end{array}$ & & \\
\hline & LLC cell & $5-160 \mu \mathrm{M}$ & $\begin{array}{l}\text { Inhibited cell proliferation } \\
\text { Induced apoptosis } \\
\text { Downregulated KDR/flk-1 in mRNA and protein level }\end{array}$ & {$[83]$} \\
\hline & NCI-H1975 cell & $5-100 \mu \mathrm{M}$ & $\begin{array}{l}\text { Inhibited cell proliferation } \\
\text { Induced apoptosis }\end{array}$ & {$[84]$} \\
\hline & A549, PC-9 cells & $10-64 \mu \mathrm{M}$ & $\begin{array}{l}\text { Inhibited cell viability and colony formation } \\
\text { Induced apoptosis } \\
\text { Inhibited the glucose uptake } \\
\text { Decreased ATP and lactate levels } \\
\text { Downregulated p-mTOR activation and GLUT1 expression } \\
\text { Increased ROS production }\end{array}$ & {$[92]$} \\
\hline & $\begin{array}{l}\text { H1975, HCC } 827, \text { H1650, H3255 } \\
\text { A549, H727,H1299,MV522 cells }\end{array}$ & $2.5-20 \mu \mathrm{M}$ & $\begin{array}{l}\text { Enhanced ABT-263-induced apoptosis } \\
\text { Induced apoptosis } \\
\text { Downregulated Mcl-1, survivin } \\
\text { Suppressed STAT3 phosphorylation }\end{array}$ & {$[96]$} \\
\hline & H1975 tumor xenograft model & $25 \mathrm{mg} / \mathrm{kg} /$ day for 15 days (i.g.) & Inhibited tumor growth & [96] \\
\hline & A549 cell & $15-90 \mu \mathrm{M}$ & $\begin{array}{l}\text { Inhibited cell proliferation } \\
\text { Decreased colony formation } \\
\text { Induced DNA damage } \\
\text { Enhanced the intracellular ROS levels } \\
\text { Induced cell cycle arrest at G2/M phase } \\
\text { Induced apoptosis }\end{array}$ & [105] \\
\hline $\begin{array}{l}\text { Breast } \\
\text { cancer }\end{array}$ & T-47D cell & $20-60 \mu \mathrm{M}$ & $\begin{array}{l}\text { Inhibited cell proliferation } \\
\text { Induced apoptosis } \\
\text { Upregulated caspase-8 and cleaved caspase-9; activated Bid and Bim } \\
\text { Downregulated Bcl-2 } \\
\text { Released cytochrome c from mitochondria into the cytosol }\end{array}$ & {$[20]$} \\
\hline & $\begin{array}{l}\text { MDA-MB-231, MCF7, } \\
\text { SKBR3, BT-474 cells }\end{array}$ & $20,50 \mu \mathrm{M}$ & $\begin{array}{l}\text { Downregulated TCTP and phospho-TCTP in protein level } \\
\text { TCTP knocking down in MDA cells enhanced the cytotoxicity of DHA }\end{array}$ & {$[30]$} \\
\hline & CHMm cell & $5-20 \mu \mathrm{M}$ & $\begin{array}{l}\text { Inhibited cell proliferation } \\
\text { Inhibited TGF- } \beta 1 \text {-induced migration and invasion } \\
\text { Downregulated Slug, ZEB1, ZEB2 and Twist in mRNA level }\end{array}$ & {$[40]$} \\
\hline & 4T1, CAFs, L-929-CAFs cells & $30,50 \mu \mathrm{M}$ & $\begin{array}{l}\text { Inhibited CAFs and L-929-CAFs activation } \\
\text { Suppressed TGF- } \beta \text { pathway }\end{array}$ & {$[42]$} \\
\hline & $\begin{array}{l}\text { 4T1-luciferase cells tumor } \\
\text { xenograft model; } \\
\text { 4T1-luciferase cells plus L-929 } \\
\text { cells tumor xenograft model }\end{array}$ & 100 mg/kg/day for 28 days (i.g.) & $\begin{array}{l}\text { Suppressed CAFs-induced cancer growth and metastasis } \\
\text { Suppressed TGF- } \beta \text { signaling }\end{array}$ & {$[42]$} \\
\hline & MDA-MB-231 cell & $1.56-6.25 \mu \mathrm{M}$ & $\begin{array}{l}\text { Suppressed AKT/SRC signaling pathway } \\
\text { Inhibited cell proliferation, migration and invasion }\end{array}$ & {$[50]$} \\
\hline & $\begin{array}{l}\text { a. Te calvarial osteolysis mice } \\
\text { model } \\
\text { b. MDA-MB-231 tumor xenograft } \\
\text { model }\end{array}$ & $\begin{array}{l}\text { a. } 50 \text { and } 100 \mu \mathrm{g} / \mathrm{kg} / \text { day for } 10 \text { days } \\
\text { b. } 100 \mu \mathrm{g} / \mathrm{kg} \text { every other day for } 28 \\
\text { days (i.p.) }\end{array}$ & $\begin{array}{l}\text { a. Suppressed titanium-particle-induced osteolysis } \\
\text { b. Inhibited breast cancer bone metastasis and osteolysis }\end{array}$ & {$[50]$} \\
\hline & RIN cell & $25-50 \mu \mathrm{M}$ & Inhibited cell proliferation & {$[58]$} \\
\hline & $\begin{array}{l}\text { a. sRBC tumor xenograft model } \\
\text { b. SMMT }\end{array}$ & $\begin{array}{l}\text { a. } 1.95-4.85 \mu \mathrm{g} / \text { mouse/day for } 24,48 \\
\text { and } 72 \mathrm{~h} \text { (footpad injection) } \\
\text { b. } 4.85 \mu \mathrm{g} / \text { mouse/day for } 6 \text { days (i.p.) }\end{array}$ & $\begin{array}{l}\text { a. Increased in DTH response } \\
\text { b. Inhibited tumor volume; increased lymphocyte proliferation index; } \\
\text { upregulated IFN-ץ; downregulated IL-4; decreased splenic } \\
\text { CD } 4^{+} \mathrm{CD} 25^{+} \mathrm{Foxp} 3^{+} \text {T regulatory lymphocytes }\end{array}$ & {$[58]$} \\
\hline & HTB 27 cell & $200 \mu \mathrm{M}$ & Inhibited cell proliferation & {$[78]$} \\
\hline $\begin{array}{l}\text { Prostate } \\
\text { cancer }\end{array}$ & PC-3 cell & $25-200 \mu \mathrm{M}$ & $\begin{array}{l}\text { Inhibited cell proliferation } \\
\text { Downregulated HSP70 in mRNA and protein level } \\
\text { Upregulated Apaf-1, caspase-3, AIF protein expression }\end{array}$ & {$[32]$} \\
\hline & LNCaP cell & $10-160 \mu \mathrm{M}$ & $\begin{array}{l}\text { Inhibited cell proliferation } \\
\text { Downregulated HIF-1a by PI3K/AKT pathway }\end{array}$ & {$[34]$} \\
\hline & $\begin{array}{l}\text { C4, C4-2, C4-2B, } \\
\text { DU145, PC-3, LNCaP cells }\end{array}$ & $5 \mu \mathrm{M}$ & $\begin{array}{l}\text { Inhibited cell proliferation } \\
\text { Inhibited migration and invasion } \\
\text { Inhibited Axl expression by inducing miR-7 and miR-34a expression }\end{array}$ & {$[51]$} \\
\hline & DU145 tumor xenograft model & $40 \mathrm{mg} / \mathrm{kg} /$ day for 50 days (i.p.) & $\begin{array}{l}\text { Inhibited tumor growth } \\
\text { Downregulated IL-6 }\end{array}$ & {$[51]$} \\
\hline & PC-3, DU145 cells & $100 \mu \mathrm{M}$ & Induced apoptosis & [77] \\
\hline & DU145, PC3, LNCaP cells & $50 \mu \mathrm{M}$ & $\begin{array}{l}\text { Inhibited cell proliferation } \\
\text { Induced caspases } 3,8 \text { and } 9 \text { activation } \\
\text { Suppressed Akt phosphorylation } \\
\text { Inhibited ERK1/ERK2 phosphorylation } \\
\text { Upregulated DR5 in protein } \\
\text { Increased DR5 promoter activity }\end{array}$ & [97] \\
\hline $\begin{array}{l}\text { Ovarian } \\
\text { cancer }\end{array}$ & $\begin{array}{l}\text { OVCA-420, OVCA-432, } \\
\text { SKOV3, OVCAR-3 cells }\end{array}$ & $2-20 \mu \mathrm{M}$ & $\begin{array}{l}\text { Induced apoptosis and cell cycle arrest at } \mathrm{G} 2 \text { phase } \\
\text { Decreased Bcl- } \mathrm{x}_{\mathrm{L}} \text { and } \mathrm{Bcl}-2 \\
\text { Increased } \mathrm{Bax} \text { and Bad }\end{array}$ & [29] \\
\hline & HO8910PM cell & $12.5-50 \mu \mathrm{M}$ & $\begin{array}{l}\text { Inhibited cell proliferation, adhesion, migration and invasion } \\
\text { Downregulated pFAK, MMP-2, vWF and macrophage infiltration }\end{array}$ & [43] \\
\hline & $\begin{array}{l}\text { HO8910PM tumor xenograft } \\
\text { model }\end{array}$ & $\begin{array}{l}50 \mathrm{mg} / \mathrm{kg} \text { three times a week for } 4 \\
\text { weeks (i.p.) }\end{array}$ & Inhibited tumor metastasis & [43] \\
\hline
\end{tabular}




\begin{tabular}{|c|c|c|c|c|}
\hline & Hela, JAR, RD, HO-8910 cells & $2.5-50 \mu \mathrm{M}$ & $\begin{array}{l}\text { Inhibited cell proliferation } \\
\text { Inhibited proliferation, migration and tube formation of HUVECs }\end{array}$ & {$[53]$} \\
\hline & EOC, SKOV3 cells & $30 \mu \mathrm{M}, 50 \mu \mathrm{M}$ & $\begin{array}{l}\text { Inhibited cell proliferation } \\
\text { Induced cell cycle arrest at } \mathrm{G} 2 / \mathrm{M} \text { phase } \\
\text { Induced autophagy } \\
\text { Suppressed NF-KB signaling pathway }\end{array}$ & {$[62]$} \\
\hline & A2780, OVCAR- 3 cells & $5-50 \mu \mathrm{M}$ & $\begin{array}{l}\text { Inhibited cell proliferation } \\
\text { Induced apoptosis } \\
\text { Released cytochrome c from the mitochondria to the cytosol } \\
\text { Upregulated fas, FADD, Bax, cleaved-PARP } \\
\text { Downregulated Bcl-2 and Bid }\end{array}$ & {$[82]$} \\
\hline & $\begin{array}{l}\text { A2780 and OVCAR-3 tumor } \\
\text { xenograft model }\end{array}$ & $\begin{array}{l}10 \text { and } 25 \mathrm{mg} / \mathrm{kg} / 5 \text { days/week for } 3 \\
\text { weeks (i.p.) }\end{array}$ & $\begin{array}{l}\text { Inhibited tumor growth } \\
\text { Downregulated the ratio of Bcl-2/Bax and p-caspase- } 8\end{array}$ & {$[82]$} \\
\hline & SKOV3 cell & $2.5-80 \mu \mathrm{M}$ & $\begin{array}{l}\text { Inhibited cell proliferation } \\
\text { Induced cell cycle arrest at } S \text { and } G 2 / M \text { phase } \\
\text { Induced apoptosis } \\
\text { Downregulated MK levels of mRNA and protein }\end{array}$ & {$[86]$} \\
\hline & SKOV3 cell xenograft tumor & $\begin{array}{l}30 \mathrm{mg} / \mathrm{kg} \text { every two days for } 5 \text { weeks } \\
\text { (i.p.) }\end{array}$ & Inhibited cell proliferation & {$[86]$} \\
\hline & $\begin{array}{l}\text { HeLa, OVCAR-3, MCF-7, } \\
\text { PC-3, A549 cells }\end{array}$ & $0.5-20 \mu \mathrm{M}$ & $\begin{array}{l}\text { Inhibited cell proliferation } \\
\text { Induced apoptosis }\end{array}$ & {$[90]$} \\
\hline & HeLa tumor xenograft model & $\begin{array}{l}15 \mathrm{mg} / \mathrm{kg} \text { for } 35 \text { days } \\
\text { (intratumoral injection) }\end{array}$ & Inhibited tumor growth & {$[90]$} \\
\hline & $\begin{array}{l}\text { OVCAR3, A2780, SKOV3, } \\
\text { OVCAR5 cells }\end{array}$ & $5-25 \mu \mathrm{M}$ & $\begin{array}{l}\text { Inhibited cell proliferation } \\
\text { Induced apoptosis } \\
\text { Downregulated PDGFRa expression } \\
\text { Repressed EMT phenotype } \\
\text { Inhibited cell migration } \\
\text { Inhibited PI3K/AKT and MAPK pathways }\end{array}$ & {$[91]$} \\
\hline & A2780 cell xenograft tumor & $\begin{array}{l}10 \text { or } 25 \mathrm{mg} / \mathrm{kg}, 5 \text { days/week for } 4 \\
\text { weeks (i.p.) }\end{array}$ & $\begin{array}{l}\text { Inhibited cell tumor growth and migration } \\
\text { Downregulated PDGFRa expression } \\
\text { Repressed EMT phenotype } \\
\text { Inhibited PI3K/AKT and MAPK pathways }\end{array}$ & {$[91]$} \\
\hline & SKOV3, SKOV3/DDP cells & $10-80 \mu \mathrm{M}$ & $\begin{array}{l}\text { Induced cell cycle arrest and autophagy } \\
\text { Downregulated c-Myc, cyclin A and p-mTOR activity }\end{array}$ & [103] \\
\hline $\begin{array}{l}\text { Esophageal } \\
\text { cancer }\end{array}$ & Eca109, Ec9706 cells & $2.5-120 \mu \mathrm{M}$ & $\begin{array}{l}\text { Inhibited cell proliferation } \\
\text { Induced apoptosis } \\
\text { Induced cell cycle arrest at G0/G1 phase } \\
\text { Upregulated Bax, procaspase-9 and LC3-II } \\
\text { Downregulated Bcl-2, Bcl- } \mathrm{x}_{\mathrm{L}} \text {, procaspase-3, Cyclin E, CDK2 and CDK4 }\end{array}$ & {$[11]$} \\
\hline & $\begin{array}{l}\text { Eca109 tumor xenograft model } \\
\text { Ec9706 tumor xenograft model }\end{array}$ & $\begin{array}{l}\text { 2, } 10 \text {, or } 50 \mathrm{mg} / \mathrm{kg} / \text { day for } 2 \text { weeks } \\
\text { (i.p.) }\end{array}$ & $\begin{array}{l}\text { Inhibited tumor growth } \\
\text { Inhibited cell proliferation } \\
\text { Induced apoptosis }\end{array}$ & {$[14]$} \\
\hline & Eca109, Ec9706 cells & $10-120 \mu \mathrm{M}$ & Inhibited glycolysis & {$[35]$} \\
\hline & Eca109, Ec9706 cells & $2.5-120 \mu \mathrm{M}$ & $\begin{array}{l}\text { Inhibited cell proliferation } \\
\text { Augmented PDT-induced growth inhibition } \\
\text { Sensitized to PDT-induced apoptosis } \\
\text { Downregulated Bcl-2, NF-kB and its downstream gene expression } \\
\text { Upregulated Bax, p-caspase- } 3 \text { and p-caspase- } 9\end{array}$ & {$[101]$} \\
\hline $\begin{array}{l}\text { Hepatocellula } \\
\text { r cancer }\end{array}$ & $\begin{array}{l}\text { HepG2, PLC/PRF/5, Hep3B } \\
\text { cells }\end{array}$ & $2.5-80 \mu \mathrm{M}$ & $\begin{array}{l}\text { Inhibited cell proliferation and colony formation assay } \\
\text { Induced apoptosis and G2/M arrest } \\
\text { Released of cytochrome c } \\
\text { Downregulated Mcl-1 } \\
\text { Upregulated Bak }\end{array}$ & {$[13]$} \\
\hline & HepG2 tumor xenograft model & $\begin{array}{l}20 \mathrm{mg} / \mathrm{kg} \text { five times a week for } 4 \\
\text { weeks (i.p.) }\end{array}$ & $\begin{array}{l}\text { Inhibited tumor growth } \\
\text { Upregulated Bak and cleaved caspase } 3 \\
\text { Downregulated Mcl-1 }\end{array}$ & {$[13]$} \\
\hline & HepG2, 7402, LM3 cells & $5-40 \mu \mathrm{M}$ & $\begin{array}{l}\text { Inhibited cell proliferation } \\
\text { Downregulated ROS }\end{array}$ & {$[17]$} \\
\hline & HepG2, Huh-7, LO2, Hep3B cells & $10-150 \mu \mathrm{M}$ & $\begin{array}{l}\text { Inhibited cell proliferation } \\
\text { Induced apoptotic } \\
\text { Upregulated p-caspase- } 8,-9 \text { and }-3, \text { Bax, Bak and Bim } \\
\text { Downregulated Mcl-1 }\end{array}$ & {$[21]$} \\
\hline & SK-Hep-1 cell & $20-80 \mu \mathrm{M}$ & $\begin{array}{l}\text { Inhibited cell proliferation } \\
\text { Induced caspase-dependent apoptosis } \\
\text { Inhibited Sp1 pathway } \\
\text { Suppressed MAPK pathways }\end{array}$ & {$[22]$} \\
\hline & HepG2215 cell & $5-40 \mu \mathrm{M}$ & $\begin{array}{l}\text { Inhibited cell proliferation } \\
\text { Induced autophagy } \\
\text { Upregulated p-caspase-1, AIM2 inflammasome and intracellular ROS } \\
\text { Inhibited cell movement capacity }\end{array}$ & {$[63]$} \\
\hline & $\begin{array}{l}\text { HepG2, Hep3B, BEL-7404, } \\
\text { Huh-7 cells }\end{array}$ & $1-50 \mu \mathrm{M}$ & $\begin{array}{l}\text { Inhibited cell proliferation } \\
\text { Induced apoptosis and G1-phase cell cycle arrest } \\
\text { Downregulated cyclins and CDKs } \\
\text { Upregulated Cip1/p21 and Kip1/p27 } \\
\text { Upregulated ratio of Bax/Bcl-2, p-caspase-3 }\end{array}$ & [87] \\
\hline & $\begin{array}{l}\text { HepG2, Hep3B tumor xenograft } \\
\text { models }\end{array}$ & $\begin{array}{l}50 \text { or } 100 \mathrm{mg} / \mathrm{kg} / \text { day } \\
5 \text { days/week for } 4 \text { weeks (i.p.) }\end{array}$ & $\begin{array}{l}\text { Inhibited tumor growth } \\
\text { Downregulated Cyclin D1, Cyclin E, Cdk2, Cdk4 and E2F1 } \\
\text { Upregulated p21, p27, p-caspase-3, cleaved PARP, Rb p53, the ratio of } \\
\text { Bax/Bcl-2 and MDM2 }\end{array}$ & {$[93]$} \\
\hline & HepG2, PLC/PRF/ 5 cells & $10 \mu \mathrm{M}$ & Upregulated MAP kinases & [93] \\
\hline
\end{tabular}




\begin{tabular}{|c|c|c|c|c|}
\hline \multirow{19}{*}{$\begin{array}{l}\text { Gastric } \\
\text { cancer }\end{array}$} & & & Downregulated ERK & \\
\hline & SGC-7901, BGC823， & $2.5-80 \mu \mathrm{M}$ & Inhibited cell proliferation & [10] \\
\hline & MGC803 cells & & Induced apoptosis, G1 cell cycle arrest and senescence & \\
\hline & & & Downregulated $\mathrm{Bcl}-2$ & \\
\hline & & & Inhibited the migration and invasion & \\
\hline & & & Upregulated miR-15b and miR-16 & \\
\hline & SGC-7901 tumor xenograft & 15 and $30 \mathrm{mg} / \mathrm{kg} /$ day for 21 days & Inhibited tumor growth & [10] \\
\hline & model & (i.p.) & Downregulated Ki-67 and Bcl-2 & \\
\hline & & & Upregulated miR-15b and miR-16 & \\
\hline & SGC-7901 cell & $1.25-20 \mu \mathrm{M}$ & Inhibited the growth of $\mathrm{H}$. pylori and gastric cancer cells & {$[18]$} \\
\hline & & & Suppressed H. pylori adhesion to gastric cancer cells & \\
\hline & & & Downregulated ROS production & \\
\hline & & & Inhibited the NF-kB signaling pathway & \\
\hline & MNU and H. pylori-induced & $60 \mathrm{mg} / \mathrm{kg}$, 3 times/week for 6 cycles & Inhibited the incidence of tumor models & [18] \\
\hline & $\begin{array}{l}\text { gastric carcinogenesis mouse } \\
\text { model }\end{array}$ & & Downregulated IL-6, TNF- $\alpha$ IL-1 $\beta$, COX-2 and p-ІкBa & \\
\hline & BGC-823 cell & $10-40 \mu \mathrm{M}$ & Inhibited cell proliferation & [27] \\
\hline & & & Induced apoptosis & \\
\hline & & & Activated JNK1/2 and p38 MAPK signaling pathways & \\
\hline & BGC-823 tumor xenograft model & $\begin{array}{l}15 \text { and } 30 \mathrm{mg} / \mathrm{kg} / \text { day for } 21 \text { days } \\
\text { (i.p.) }\end{array}$ & Inhibited tumor growth & [27] \\
\hline \multirow{26}{*}{$\begin{array}{l}\text { Pancreatic } \\
\text { cancer }\end{array}$} & BxPC-3, AsPC- 1 cells & $5-80 \mu \mathrm{M}$ & Inhibited cell proliferation & {$[25]$} \\
\hline & & & Downregulated cyclin D1 and PCNA & \\
\hline & & & Upregulated $\mathrm{p} 21_{\mathrm{WAF} 1 / \mathrm{CIP} 1}$ & \\
\hline & & & Induced apoptosis & \\
\hline & BxPC-3 tumor xenograft model & 2,10 , and $50 \mathrm{mg} / \mathrm{kg} /$ day for 18 days & Inhibited tumor growth & [25] \\
\hline & & (i.p.) & Downregulated Ki-67 & \\
\hline & & & Induced apoptosis & \\
\hline & BxPC- 3, AsPC- 1 cells & $5-20 \mu \mathrm{M}$ & Induced cell cycle arrest at G0/G1 phase & [26] \\
\hline & & & Downregulated of Cyclin E, CDK2, CDK4 and CDK6 & \\
\hline & & & Inhibited translocation & \\
\hline & & & Inhibited DNA-binding activity of NF-kB/p65 & \\
\hline & BxPC-3, PANC-1 cells & $12.5-100 \mu \mathrm{M}$ & Inhibited cell proliferation & [54] \\
\hline & & & Inhibited NF-KB activation & \\
\hline & BxPC-3 tumor xenograft model & 2,10 , or $50 \mathrm{mg} / \mathrm{kg} /$ day for 21 days & Inhibited tumor growth & [54] \\
\hline & & (i.p.) & Inhibited NF-KB activation & \\
\hline & & & Downregulated VEGF, COX-2 and MMP-9 & \\
\hline & PANC-1, BxPC-3 & $50 \mu \mathrm{M}$ & Upregulated miR-34a-5p, miR-195-5p, miR-30c-5p and miR-130b-3p & [55] \\
\hline & SW1990, CFPAC-1 cells & & $\begin{array}{l}\text { Downregulated Cdk4, Cdk6, VEGF, IKKa, MEK1,E2F3, Rac1, E2F1, } \\
\text { and CDC42 in mRNA level }\end{array}$ & \\
\hline & BxPC-3 tumor xenograft model & $10 \mathrm{mg} / \mathrm{kg} /$ day for 18 days (i.p.) & Inhibited tumor growth & [55] \\
\hline & & & Inhibited angiogenesis & \\
\hline & & & Induced apoptosis & \\
\hline & SW1990, BxPC-3, PANC-1 cells & $12.5-200 \mu \mathrm{M}$ & Upregulated perforin, granzyme B, IFN- $\gamma$ & [59] \\
\hline & BxPC-3, PANC-1 cells & $12.5-50 \mu \mathrm{M}$ & Inhibited cell proliferation & {$[64]$} \\
\hline & & & Induced caspase-3-dependent cell death and autophagy & \\
\hline & & & Downregulated p-caspase-3 & \\
\hline & & & Upregulated JNK and beclin 1 & \\
\hline \multirow{16}{*}{$\begin{array}{l}\text { Colorectal } \\
\text { cancer }\end{array}$} & SW 948 cell & $10-50 \mu \mathrm{M}$ & Inhibited cell proliferation & [15] \\
\hline & & & Induced apoptosis & \\
\hline & & & Upregulated PPARY, MMP-2 and -9 & \\
\hline & & & Inhibited cell migration & \\
\hline & AOM/DSS mice model & $20 \mathrm{mg} / \mathrm{kg} /$ day for 30 days (i.p.) & Inhibited tumor growth and inflammation & [15] \\
\hline & HCT116 cell & $12.5-100 \mu \mathrm{M}$ & Inhibited cell proliferation & [23] \\
\hline & & & Induced apoptosis & \\
\hline & & & Upregulated Bax, p-caspase-3/9, p-JNK1/2 and p38 MAPK & \\
\hline & & & Downregulated PARP, p-ERK1/2, p-JAK2 and p-STAT3 & \\
\hline & HCT15, Colo205, HCT116 cells & $10-80 \mu \mathrm{M}$ & Inhibited cell proliferation & [36] \\
\hline & & & Induced apoptosis and necrotic cell death & \\
\hline & & & Induced ROS production & \\
\hline & & & Upregulated Mcl-1 & \\
\hline & HCT116 cell & $0.3-30 \mu \mathrm{M}$ & Inhibited cell proliferation, cell cycle arrest and apoptosis & [67] \\
\hline & & & Upregulated GRP78 and GADD153 in mRNA levels & \\
\hline & & & Induced ER stress & \\
\hline
\end{tabular}

i.p., Intraperitoneal; i.v., Intravenous; i.g., Intragastric

Table 2. Summary of the anticancer data about dose and effects of combination treatment with dihydroartemisinin in vitro and in vivo.

\begin{tabular}{|c|c|c|c|c|c|}
\hline Cancer type & Model type & Combination & Effective doses & Main effects & Reference \\
\hline \multirow[t]{3}{*}{$\begin{array}{l}\text { Lung } \\
\text { cancer }\end{array}$} & A549 cell & Epirubicin & $\begin{array}{l}\text { Epirubicin: } 0-5 \mu \mathrm{M} \\
\text { DHA: } 0-50 \mu \mathrm{M}\end{array}$ & $\begin{array}{l}\text { Inhibited migration, invasion and VM channels } \\
\text { Inhibited cell adhesion } \\
\text { Induced apoptosis }\end{array}$ & [73] \\
\hline & A549 cell & Epirubicin & $\begin{array}{l}\mathrm{R}_{8} \text { modified epirubicin-dihydroartemisinin } \\
\text { liposomes } \\
\text { epirubicin: } 10 \mu \mathrm{M} \\
\text { epirubicin } / \mathrm{DHA}=1: 5 \text {, molar ratio }\end{array}$ & $\begin{array}{l}\text { Inhibited migration, invasion and VM channels } \\
\text { Inhibited cell adhesion } \\
\text { Induced apoptosis }\end{array}$ & [73] \\
\hline & $\begin{array}{l}\text { A549 tumor } \\
\text { xenograft model }\end{array}$ & Cisplatin & $\begin{array}{l}\text { Cisplatin: } 2 \mathrm{mg} / \mathrm{kg} / \text { day (i.p.) } \\
\text { DHA: 50, 100, } 200 \mathrm{mg} / \mathrm{kg} / \text { day (i.p.) }\end{array}$ & $\begin{array}{l}\text { Inhibited tumor growth } \\
\text { Inhibited pulmonary metastasis }\end{array}$ & [83] \\
\hline
\end{tabular}




$\begin{array}{lll}\begin{array}{l}\text { LLC tumor } \\ \text { xenograft model }\end{array} & \text { CTX } & \begin{array}{l}\text { every other day for five times for } 25 \text { days } \\ \text { CTX: } 50 \mathrm{mg} / \mathrm{kg} / \text { day (i.p.) }\end{array} \\ & & \begin{array}{l}\text { DHA: } 50,100,200 \mathrm{mg} / \mathrm{kg} / \text { day (i.p.) } \\ \text { every other day for five times for } 25 \text { days } \\ \text { NCI-H1975 cell }\end{array} \\ & \text { GHA: } 10 \mu \mathrm{M} \\ & \text { Gefitinib } & \end{array}$

NCI-H661,

SK-MES-1,

SPC-A-1, A549 cells

A549 tumor

xenograft model

A549, PC-9 cells

2DG

H1975 tumor

xenograft model

H1975, HCC827,

H1650, H3255, A549,

H727, H1299,

MV522 cells

A549 cell

ATO

ABT-263

ABT-263

Onc

Onc

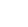

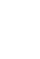

\begin{tabular}{|c|c|c|}
\hline \multirow[t]{9}{*}{$\begin{array}{l}\text { Breast } \\
\text { cancer }\end{array}$} & MDA, SKBR3 cells & $\begin{array}{l}\text { DOX } \\
\text { Cisplatin }\end{array}$ \\
\hline & SKBR3 cell & Trastuzumab \\
\hline & MDA-MB-231 cell & Rapamycin \\
\hline & $\begin{array}{l}\text { MDA-MB-435S } \\
\text { tumor xenograft } \\
\text { model }\end{array}$ & Epirubicin \\
\hline & $\begin{array}{l}\text { MDA-MB-435S, } \\
\text { MDA-MB-231, } \\
\text { MCF-7 cells }\end{array}$ & Epirubicin \\
\hline & $\begin{array}{l}\text { MDA-MB-435S, } \\
\text { MCF-7 cells }\end{array}$ & Daunorubicin \\
\hline & $\begin{array}{l}\text { MDA-MB-435S } \\
\text { tumor xenograft } \\
\text { model }\end{array}$ & Daunorubicin \\
\hline & НТВ 27 & Holotransferrin \\
\hline & $\begin{array}{l}\text { MCF-7, } \\
\text { MDA-MB-231, } \\
\text { T-47D cells }\end{array}$ & DOX \\
\hline \multirow{3}{*}{$\begin{array}{l}\text { Prostate } \\
\text { cancer }\end{array}$} & DU145 cell & Docetaxel \\
\hline & $\begin{array}{l}\text { DU145 tumor } \\
\text { xenograft model }\end{array}$ & Docetaxel \\
\hline & $\begin{array}{l}\text { DU145, PC3, LNCaP } \\
\text { cells }\end{array}$ & TRAIL \\
\hline \multirow[t]{3}{*}{$\begin{array}{l}\text { Ovarian } \\
\text { cancer }\end{array}$} & $\begin{array}{l}\text { a. A2780, OVCAR-3 } \\
\text { cells } \\
\text { b. A2780 and } \\
\text { OVCAR-3 tumor } \\
\text { xenograft models }\end{array}$ & СВР \\
\hline & $\begin{array}{l}\text { SKOV3 tumor } \\
\text { xenograft model }\end{array}$ & Cur \\
\hline & SKOV3 cell & Cur \\
\hline
\end{tabular}

DOX: $1-5 \mu \mathrm{M}$ or

Cisplatin: $50 \mu \mathrm{M}$

DHA: $50 \mu \mathrm{M}$

Trastuzumab: $50 \mu \mathrm{g} / \mathrm{ml}$

DHA: $20 \mu \mathrm{M}$

Rapamycin: $100 \mathrm{nM}$

DHA: $10 \mu \mathrm{g} / \mathrm{ml}$

DHA plus epirubicin liposomes $4 \mathrm{mg} / \mathrm{kg}$ for both drugs once

(tail vein injection)

a. DHA $10 \mu \mathrm{M}$; epirubicin $5 \mu \mathrm{M}$ (free)

b. DHA $10 \mu \mathrm{M}$; epirubicin $5 \mu \mathrm{M}$ (liposomes)

a. Daunorubicin: $0-2.5 \mu \mathrm{M}$

DHA: $2.5,5$ or $25 \mu \mathrm{M}$ (free)

b. Daunorubicin plus DHA liposomes $(0-10 \mu \mathrm{M})$ Downregulated $\alpha 5 \beta 1$-integrin, TGF- $\beta 1$, VEGF, c. OCT-modified daunorubicin plus DHA liposomes

a. Daunorubicin plus DHA liposomes

b. OCT-modified daunorubicin plus DHA

liposomes

$5 \mathrm{mg} / \mathrm{kg}$ daunorubicin (tail vein injection)

Holotransferrin: $1 \mathrm{mg} / \mathrm{ml}$

DHA: $200 \mu \mathrm{M}$ for 8 and $24 \mathrm{hrs}$

DOX: $1.25-20 \mu \mathrm{M}$

DHA: $2.5-40 \mu \mathrm{M}$

Docetaxel: $2.4-625 \mathrm{nM}$ for $24 \mathrm{~h}$

DHA: $0.0048-5 \mu \mathrm{M}$

Docetaxel: $15 \mathrm{mg} / \mathrm{kg}$ on day $1,8,15,38,45,52$

(i.p.)

DHA: 40 mg/kg/day (i.p.)

TRAIL: $10-20 \mathrm{ng} / \mathrm{ml}$

DHA: $10-30 \mu \mathrm{M}$

a. CBP $10 \mu \mathrm{M}$ plus $1 \mu \mathrm{M}$ DHA for $0,24,48$ or

$72 \mathrm{hrs}$

$500 \mu \mathrm{M}$ CBP plus $1 \mu \mathrm{M}$ DHA for $24 \mathrm{hrs}$

b. CBP: $120 \mathrm{mg} / \mathrm{kg}$, once on day 0

DHA: $25 \mathrm{mg} / \mathrm{kg} / 5$ days/week for 3 weeks (i.p.)

Cur: $20 \mathrm{mg} / \mathrm{kg}$ (i.p.)

DHA: $30 \mathrm{mg} / \mathrm{kg}$ (i.p.)

every two days for 5 weeks

Cur: $10 \mu \mathrm{M}$

DHA: $20 \mu \mathrm{M}$

Induced apoptosis
Inhibited tumor growth

Inhibited pulmonary metastasis

[83]

Inhibited cell proliferation

Induced apoptosis, cell cycle arrest in G2/M phase

Inhibited migration and invasion

Downregulated cyclin B1, Cdk1, p-Akt, p-mTOR,

p-STAT3 and Bcl-2

Upregulated Bax

Inhibited cell proliferation

Inhibited of endothelial cell tube formation

Inhibited tumor growth

Inhibited tumor angiogenesis

Inhibited glycolysis

Upregulated cytochrome c and AIF cytoplasm

Inhibited tumor growth

Induced apoptosis

Downregulated Mcl-1, survivin, p-STAT3

Inhibited cell proliferation

Induced DNA damage

Induced cell cycle arrest at $\mathrm{G} 2 / \mathrm{M}$ phase

Increased the intracellular ROS

Induced apoptosis

Inhibited cell proliferation

Induced apoptosis

Induced apoptosis

Inhibited cell proliferation

Induced apoptosis

Upregulated Atg7 and DAPK mRNA levels

Inhibited cell proliferation

Inhibited cell proliferation

Induced autophagy and apoptosis

Upregulated caspase-9, caspase-3, Bax, Beclin 1,

LC3B and ROS

Downregulated Bcl-2

Inhibited cell proliferation

Inhibited migration

MMP2 and MMP9

Increased drug accumulation at tumor sites

Inhibited tumor growth

Inhibited cell proliferation

Inhibited cell proliferation

Induced apoptosis

Inhibited cell proliferation

Inhibited tumor growth

Downregulated IL-6

Prolonged survival

Inhibited cell proliferation

Upregulated pro-caspases 8, 9 and 3

Induced apoptosis

Induced apoptosis

Inhibited tumor growth

Downregulated the Bcl-2/Bax ratio and

pro-caspase- 8

Inhibited tumor growth

Inhibited cell proliferation

Induced apoptosis and cell cycle arrest at $\mathrm{S}$ and

$\mathrm{G} 2 / \mathrm{M}$

Downregulated Bcl-2, MK levels of mRNA and protein 




i.p., Intraperitoneal; i.v., Intravenous; i.g., Intragastric

\section{Conclusion}

The research of anticancer effect of DHA is promising. Evidence suggests that DHA has powerful anti-tumor efficacy. This review systematically summarized the pharmacological effects and potential molecular mechanisms of DHA in vitro and in vivo. Furthermore, new methods to improve the water solubility and bioavailability of DHA as well as the combination medication were also discussed which highlighted the application prospects of DHA as an anticancer drug. Moreover, clinical trials further demonstrated the powerful anti-tumor effect of DHA. It is worth noting that, the molecular mechanism of DHA against tumors is not comprehensive and unsolved potential toxicity questions are notable deficiencies. Moreover, bioinformatics and experimental analysis of drug interactions are also needed in order to better understand the role of DHA in the body. Interestingly, there is evidence that DHA has potential efficacy on immune cells in the tumor microenvironment, and DHA might be considered in combination with immunotherapy in the future. Comprehensive research is required so that DHA can become a highly effective and low toxicity anticancer drug for the benefit of patients.

\section{Abbreviations}

AKT: the protein kinase B; Apo2L: Apo2 ligand; ARTs: artemisinin and its derivatives; Atg7: autophagy-related 7; ATO: arsenic trioxide; CAFs: cancer-associated fibroblasts; CBP: carboplatin; CD71: transferrin receptor protein 1; CDT: chemodynamic therapy; CTX: cyclophosphamide; Cur: curcumin; CYP: cytochrome P450; DAPK: deathassociated protein kinase; DDI: drug-drug interaction; DFO: deferoxamine mesylate salt; DHA: dihydroartemisinin; DOX: doxorubicin; DTH: delayed type hypersensitivity; EGFR: epidermal growth factor receptor; EMT: epithelial-mesenchymal transition; EOC: epithelial ovarian cancer; ER stress: endoplasmic reticulum stress; ERK: extracellular signal-regulated kinase; FTS: farnesylthiosalicylic acid; GADD153: DNA damage-inducing gene 153; GEL: gelatine; GLS1: glutaminase; GLUT1: glucose transporter-1; GRP78: Glucose regulatory protein 78; Gsk3 $\beta$ : glycogen synthase kinase-3 $\beta ; H$. pylori: Helicobacter pylori; HA: hyaluronic acid; HCC: hepatocellular carcinoma; HDACis: histone deacetylase inhibitors; HIF-1a: hypoxia inducible factor-1a; HSP70: heat-shock protein 70; HUVECs: human umbilical vein endothelial cells; JAK2: janus kinase 2; JNK1/2: c-Jun $\mathrm{NH}_{2}$-terminal kinases; LLC: 
Lewis lung carcinoma; MK: midkine; MMPs: matrix metalloproteinases; MNP: magnetic nanoparticles; mTOR: mammalian target of rapamycin; NF-kB: nuclear factor kappa B; NSCLC: non-small cell lung cancer; OCT: octreotide; Onc: Onconase; p38 MAPK: p38 mitogen-activated protein kinase; PARP: poly ADP-ribose polymerase; PDGFR $\alpha$ : platelet-derived growth factor receptor-alpha; PDT: photodynamic therapy; PEG-DHA: polyethylene glycol-dihydroartemisinin; pFAK: phosphorylated focal adhesion kinase; PI3K: phosphatidyl-inositol-3-kinase; PKM2: pyruvate kinase M2; PPARY: peroxisome proliferatoractivated receptor $\gamma$; ROS: reactive oxygen species; SMMT: spontaneous mouse mammary tumor; Sp1: specificity protein 1 ; sRBC: sheep red blood cell; SRC: steroid receptor coactivator; STAT3: signal transducer and activator of transcription 3; TCTP: translationally controlled tumor protein; TfRs: transferrin receptor; TGF- $\beta$ : transforming growth factor- $\beta$; TRAIL: tumor necrosis factor-related apoptosis inducing ligand; uPA: urokinase-type plasminogen activator; VEGF: vascular endothelial growth factor; VM: vasculogenic mimicry; vWF: von willebrand factor.

\section{Acknowledgments}

This work was supported by the Natural Science Foundation of China (no.81572972), the Supporting Plan of Scientific and Technological Innovation Team in Universities of Henan Province (no.20IRTSTHN029), the Research Project on educational and teaching reform of Zhengzhou University (no.2019ZZUJGLX177), and the Key scientific and technological research projects of Henan Provincial Department of Education (no.20B310018).

\section{Author contributions}

Conceptualization, X.D. and J.L.; Investigation, X.Z., W.C. and Y.C.; Visualization, X.Z., Q.Z. and S.M.; Writing - Original Draft, X.D.; Writing - Review \& Editing, S.M. and J.L.; Supervision, J.L. All authors have read and agreed to the published version of the manuscript.

\section{Competing Interests}

The authors have declared that no competing interest exists.

\section{References}

1. Klayman DL. Qinghaosu (artemisinin): an antimalarial drug from China. Science. 1985; 228: 1049-55.

2. Neill US. From branch to bedside: Youyou Tu is awarded the 2011 Lasker DeBakey Clinical Medical Research Award for discovering artemisinin as a treatment for malaria. J Clin Invest. 2011; 121: 3768-73.

3. Efferth T. From ancient herb to modern drug: Artemisia annua and artemisinin for cancer therapy. Semin Cancer Biol. 2017; 46: 65-83.
4. Tu Y. The discovery of artemisinin (qinghaosu) and gifts from Chinese medicine. Nat Med. 2011; 17: 1217-20.

5. Li WD, Dong YJ, Tu YY, Lin ZB. Dihydroarteannuin ameliorates lupus symptom of BXSB mice by inhibiting production of TNF-alpha and blocking the signaling pathway NF-kappa B translocation. Int Immunopharmacol. 2006; 6: 1243-50.

6. Parkin DM, Bray F, Ferlay J, Pisani P. Estimating the world cancer burden: Globocan 2000. Int J Cancer. 2001; 94: 153-6.

7. Chou TC. Theoretical basis, experimental design, and computerized simulation of synergism and antagonism in drug combination studies. Pharmacol Rev. 2006; 58: 621-81.

8. Roth AD, Maibach R, Martinelli G, Fazio N, Aapro MS, Pagani O, et al. Docetaxel (Taxotere)-cisplatin (TC): an effective drug combination in gastric carcinoma. Swiss Group for Clinical Cancer Research (SAKK), and the European Institute of Oncology (EIO). Ann Oncol. 2000; 11: 301-6.

9. Slezakova S, Ruda-Kucerova J. Anticancer Activity of Artemisinin and its Derivatives. Anticancer Res. 2017; 37: 5995-6003.

10. Sun H, Meng X, Han J, Zhang Z, Wang B, Bai X, et al. Anti-cancer activity of DHA on gastric cancer--an in vitro and in vivo study. Tumour Biol. 2013; 34: 3791-800.

11. Du XX, Li YJ, Wu CL, Zhou JH, Han Y, Sui H, et al. Initiation of apoptosis, cell cycle arrest and autophagy of esophageal cancer cells by dihydroartemisinin. Biomed Pharmacother. 2013; 67: 417-24.

12. Liao K, Li J, Wang ZL. Dihydroartemisinin inhibits cell proliferation via AKT/GSK3 beta/cyclinD1 pathway and induces apoptosis in A549 lung cancer cells. Int J Clin Exp Patho. 2014; 7: 8684-91.

13. Zhang CZ, Zhang HT, Yun JP, Chen GG, Lai PBS. Dihydroartemisinin exhibits antitumor activity toward hepatocellular carcinoma in vitro and in vivo. Biochemical Pharmacology. 2012; 83: 1278-89.

14. Jiang C, Li S, Li Y, Bai Y. Anticancer Effects of Dihydroartemisinin on Human Esophageal Cancer Cells In vivo. Anal Cell Pathol (Amst). 2018; 2018: 8759745.

15. Lu ZH, Peng JH, Zhang RX, Wang F, Sun HP, Fang YJ, et al. Dihydroartemisinin inhibits colon cancer cell viability by inducing apoptosis through up-regulation of PPAR gamma expression. Saudi J Biol Sci. 2018; 25: 372-6.

16. Han P, Luan Y, Liu YL, Yu ZW, Li JW, Sun ZC, et al. Small interfering RNA targeting Rac1 sensitizes colon cancer to dihydroartemisinin-induced cell cycle arrest and inhibited cell migration by suppressing NF kappa B activity. Mol Cell Biochem. 2013; 379: 171-80.

17. Wang $D$, Meng $G$, Zheng $M$, Zhang $Y$, Chen $A, W u$ J, et al. The Glutaminase-1 Inhibitor 968 Enhances Dihydroartemisinin-Mediated Antitumor Efficacy in Hepatocellular Carcinoma Cells. PLoS One. 2016; 11: e0166423.

18. Su T, Li F, Guan I, Liu L, Huang P, Wang Y, et al. Artemisinin and its derivatives prevent Helicobacter pylori-induced gastric carcinogenesis via inhibition of NF-kappaB signaling. Phytomedicine. 2019; 63: 152968.

19. Fiandalo MV, Kyprianou N. Caspase control: protagonists of cancer cell apoptosis. Exp Oncol. 2012; 34: 165-75.

20. Mao H, Gu H, Qu X, Sun J, Song B, Gao W, et al. Involvement of the mitochondrial pathway and Bim/Bcl-2 balance in dihydroartemisinin-induced apoptosis in human breast cancer in vitro. Int J Mol Med. 2013; 31: 213-8.

21. Qin G, Zhao C, Zhang L, Liu H, Quan Y, Chai L, et al. Dihydroartemisinin induces apoptosis preferentially via a Bim-mediated intrinsic pathway in hepatocarcinoma cells. Apoptosis. 2015; 20: 1072-86.

22. Im E, Yeo C, Lee HJ, Lee EO. Dihydroartemisinin induced caspase-dependent apoptosis through inhibiting the specificity protein 1 pathway in hepatocellular carcinoma SK-Hep-1 cells. Life Sciences. 2018; 192: 286-92.

23. Wang DS, Zhong B, Li Y, Liu XD. Dihydroartemisinin increases apoptosis of colon cancer cells through targeting Janus kinase $2 /$ signal transducer and activator of transcription 3 signaling. Oncology Letters. 2018; 15: 1949-54.

24. Fan HN, Zhu MY, Peng SQ, Zhu JS, Zhang J, Qu GQ. Dihydroartemisinin inhibits the growth and invasion of gastric cancer cells by regulating cyclin D1-CDK4-Rb signaling. Pathol Res Pract. 2020; 216: 152795.

25. Chen H, Sun B, Pan S, Jiang H, Sun X. Dihydroartemisinin inhibits growth of pancreatic cancer cells in vitro and in vivo. Anticancer Drugs. 2009; 20: 131-40.

26. Chen H, Sun B, Wang S, Pan S, Gao Y, Bai X, et al. Growth inhibitory effects of dihydroartemisinin on pancreatic cancer cells: involvement of cell cycle arrest and inactivation of nuclear factor-kappaB. J Cancer Res Clin Oncol. 2010; 136: 897-903.

27. Zhang S, Shi L, Ma H, Li H, Li Y, Lu Y, et al. Dihydroartemisinin induces apoptosis in human gastric cancer cell line BGC-823 through activation 
of JNK1/2 and p38 MAPK signaling pathways. J Recept Signal Transduct Res. 2017; 37: 174-80.

28. Mu D, Zhang W, Chu D, Liu T, Xie Y, Fu E, et al. The role of calcium, P38 MAPK in dihydroartemisinin-induced apoptosis of lung cancer PC-14 cells. Cancer Chemother Pharmacol. 2008; 61: 639-45.

29. Jiao Y, Ge CM, Meng QH, Cao JP, Tong J, Fan SJ. Dihydroartemisinin is an inhibitor of ovarian cancer cell growth. Acta Pharmacol Sin. 2007; 28: 1045-56.

30. Lucibello M, Adanti S, Antelmi E, Dezi D, Ciafre S, Carcangiu ML, et al. Phospho-TCTP as a therapeutic target of dihydroartemisinin for aggressive breast cancer cells. Oncotarget. 2015; 6: 5275-91.

31. Xu G, Zou WQ, Du SJ, Wu MJ, Xiang TX, Luo ZG. Mechanism of dihydroartemisinin-induced apoptosis in prostate cancer PC3 cells: An iTRAQ-based proteomic analysis. Life Sci. 2016; 157: 1-11.

32. Kong J, Li SS, Ma Q, Liu L, Zheng LJ. Effects of dihydroartemisinin on HSP70 expression in human prostate cancer PC-3 cells. Andrologia. 2019; 51: e13280.

33. Molina JR, Adjei AA, Jett JR. Advances in chemotherapy of non-small cell lung cancer. Chest. 2006; 130: 1211-9.

34. Zhu W, Li Y, Zhao D, Li H, Zhang W, Xu J, et al. Dihydroartemisinin suppresses glycolysis of LNCaP cells by inhibiting PI3K/AKT pathway and downregulating HIF-1alpha expression. Life Sci. 2019; 233: 116730.

35. Li S, Huang P, Gan J, Ling X, Du X, Liao Y, et al. Dihydroartemisinin represses esophageal cancer glycolysis by down-regulating pyruvate kinase M2. Eur J Pharmacol. 2019; 854: 232-9.

36. Ontikatze T, Handrick R, Grimm F, Henke G, Daniel PT, Belka C, et al. Dihydroartemisinin is a hypoxia active anticancer drug. Ejc Suppl. 2010; 8: 94-.

37. Nguyen DX, Massague J. Genetic determinants of cancer metastasis. Nat Rev Genet. 2007; 8: 341-52.

38. Rasheed SAK, Efferth T, Asangani IA, Allgayer H. First evidence that the antimalarial drug artesunate inhibits invasion and in vivo metastasis in lung cancer by targeting essential extracellular proteases. International Journal of Cancer. 2010; 127: 1475-85.

39. Deng W, Long L, Li JL, Zheng D, Yu JH, Zhang CY, et al. Mortality of Major Cancers in Guangxi, China: Sex, Age and Geographical Differences from 1971 and 2005. Asian Pac J Cancer P. 2014; 15: 1567-74.

40. Dong J, Yang W, Han J, Cheng R, Guo X, Li L. Effect of dihydroartemisinin on epithelial-to-mesenchymal transition in canine mammary tumour cells. Res Vet Sci. 2019; 124: 240-7.

41. Li N, Zhang S, Luo Q, Yuan F, Feng R, Chen X, et al. The Effect of Dihydroartemisinin on the Malignancy and Epithelial-Mesenchymal Transition of Gastric Cancer Cells. Curr Pharm Biotechnol. 2019.

42. Yao Y, Guo Q, Cao Y, Qiu Y, Tan R, Yu Z, et al. Artemisinin derivatives inactivate cancer-associated fibroblasts through suppressing TGF-beta signaling in breast cancer. J Exp Clin Cancer Res. 2018; 37: 282.

43. Wu B, Hu K, Li S, Zhu J, Gu L, Shen H, et al. Dihydroartiminisin inhibits the growth and metastasis of epithelial ovarian cancer. Oncol Rep. 2012; 27: $101-8$

44. Chen R, Lu X, Li Z, Sun Y, He Z, Li X. Dihydroartemisinin Prevents Progression and Metastasis of Head and Neck Squamous Cell Carcinoma by Inhibiting Polarization of Macrophages in Tumor Microenvironment. Onco Targets Ther. 2020; 13: 3375-87.

45. Zhang S, Ma Y, Jiang J, Dai Z, Gao X, Yin X, et al. Inhibition of urokinase-type plasminogen activator expression by dihydroartemisinin in breast cancer cells. Oncol Lett. 2014; 7: 1375-80.

46. Tong YL, Liu YT, Zheng HM, Zheng L, Liu WQ, Wu JJ, et al. Artemisinin and its derivatives can significantly inhibit lung tumorigenesis and tumor metastasis through Wnt/beta-catenin signaling. Oncotarget. 2016; 7: 31413-28.

47. Jiang J, Geng GJ, Yu XY, Liu HM, Gao J, An HX, et al. Repurposing the anti-malarial drug dihydroartemisinin suppresses metastasis of non-small-cell lung cancer via inhibiting NF-kappa B/GLUT1 axis. Oncotarget. 2016; 7: 87271-83.

48. Liu Y, Gao S, Zhu J, Zheng Y, Zhang H, Sun H. Dihydroartemisinin induces apoptosis and inhibits proliferation, migration, and invasion in epithelial ovarian cancer via inhibition of the hedgehog signaling pathway. Cancer Med. 2018; 7: 5704-15.

49. Wu L, Cheng Y, Deng J, Tao W, Ye J. Dihydroartemisinin Inhibits Proliferation and Induces Apoptosis of Human Hepatocellular Carcinoma Cell by Upregulating Tumor Necrosis Factor via JNK/NF-kappaB Pathways. Evid Based Complement Alternat Med. 2019; 2019: 9581327.

50. Feng MX, Hong JX, Wang Q, Fan YY, Yuan CT, Lei $X H$, et al. Dihydroartemisinin prevents breast cancer-induced osteolysis via inhibiting both breast cancer cells and osteoclasts. Sci Rep. 2016; 6: 19074.

51. Paccez JD, Duncan K, Sekar D, Correa RG, Wang Y, Gu X, et al. Dihydroartemisinin inhibits prostate cancer via
JARID2/miR-7/miR-34a-dependent downregulation of Axl. Oncogenesis. 2019; 8: 14.

52. McDougall SR, Anderson AR, Chaplain MA. Mathematical modelling of dynamic adaptive tumour-induced angiogenesis: clinical implications and therapeutic targeting strategies. J Theor Biol. 2006; 241: 564-89.

53. Chen H. Inhibition of human cancer cell line growth and human umbilical vein endothelial cell angiogenesis by artemisinin derivatives in vitro. Pharmacological Research. 2003; 48: 231-6.

54. Wang SJ, Sun B, Cheng ZX, Zhou HX, Gao Y, Kong R, et al. Dihydroartemisinin inhibits angiogenesis in pancreatic cancer by targeting the NF-kappaB pathway. Cancer Chemother Pharmacol. 2011; 68: 1421-30.

55. Li YL, Wang YW, Kong $\mathrm{R}$, Xue DB, Pan $\mathrm{SH}$, Chen $\mathrm{H}$, et al. Dihydroartemisinin suppresses pancreatic cancer cells via a microRNA-mRNA regulatory network. Oncotarget. 2016; 7: 62460-73.

56. Liu J, Ren YJ, Hou YL, Zhang CQ, Wang B, Li XR, et al. Dihydroartemisinin Induces Endothelial Cell Autophagy through Suppression of the Akt/mTOR Pathway. J Cancer. 2019; 10: 6057-64

57. Niu N, Yu CM, Li LQ, Liu Q, Zhang WQ, Liang KL, et al. Dihydroartemisinin enhances VEGFR1 expression through up-regulation of ETS-1 transcription factor. J Cancer. 2018; 9: 3366-72.

58. Noori S, Hassan ZM. Dihydroartemisinin shift the immune response towards Th1, inhibit the tumor growth in vitro and in vivo. Cell Immunol. 2011; 271: 67-72.

59. Zhou ZH, Chen FX, Xu WR, Qian H, Sun LQ, Lu XT, et al. Enhancement effect of dihydroartemisinin on human gammadelta $\mathrm{T}$ cell proliferation and killing pancreatic cancer cells. Int Immunopharmacol. 2013; 17: 850-7.

60. Yu R, Jin L, Li F, Fujimoto M, Wei Q, Lin Z, et al. Dihydroartemisinin inhibits melanoma by regulating CTL/Treg anti-tumor immunity and STAT3-mediated apoptosis via IL-10 dependent manner. J Dermatol Sci. 2020

61. Motyl T, Gajkowska B, Zarzynska J, Gajewska M, Lamparska-Przybysz M. Apoptosis and Autophagy in Mammary Gland Remodeling and Breast Cancer Chemotherapy. J Physiol Pharmacol. 2006; 57: 17-32.

62. Li B, Bu S, Sun J, Guo Y, Lai D. Artemisinin derivatives inhibit epithelial ovarian cancer cells via autophagy-mediated cell cycle arrest. Acta Biochim Biophys Sin (Shanghai). 2018; 50: 1227-35.

63. Shi X, Wang L, Ren L, Li J, Li S, Cui Q, et al. Dihydroartemisinin, an antimalarial drug, induces absent in melanoma 2 inflammasome activation and autophagy in human hepatocellular carcinoma HepG2215 cells. Phytother Res. 2019; 33: 1413-25.

64. Jia G, Kong R, Ma ZB, Han B, Wang YW, Pan SH, et al. The activation of c-Jun NH2-terminal kinase is required for dihydroartemisinin-induced autophagy in pancreatic cancer cells. J Exp Clin Canc Res. 2014; 33.

65. Chen X, He LY, Lai S, He Y. Dihydroartemisinin inhibits the migration of esophageal cancer cells by inducing autophagy. Oncol Lett. 2020; 20: 94.

66. Liu Q, Zhou X, Li C, Zhang X, Li CL. Rapamycin promotes the anticancer action of dihydroartemisinin in breast cancer MDA-MB-231 cells by regulating expression of Atg7 and DAPK. Oncol Lett. 2018; 15: 5781-6.

67. Lu JJ, Chen SM, Zhang XW, Ding J, Meng LH. The anti-cancer activity of dihydroartemisinin is associated with induction of iron-dependent endoplasmic reticulum stress in colorectal carcinoma HCT116 cells. Invest New Drug. 2011; 29: 1276-83.

68. Elhassanny AEM, Soliman E, Marie M, McGuire P, Gul W, ElSohly M, et al. Heme-Dependent ER Stress Apoptosis: A Mechanism for the Selective Toxicity of the Dihydroartemisinin, NSC735847, in Colorectal Cancer Cells. Front Oncol. 2020; 10: 965.

69. Galal AM, Gul W, Slade D, Ross SA, Feng S, Hollingshead MG, et al. Synthesis and evaluation of dihydroartemisinin and dihydroartemisitene acetal dimers showing anticancer and antiprotozoal activity. Bioorgan Med Chem. 2009; 17: 741-51.

70. Sun Q, Teong B, Chen IF, Chang SJ, Gao J, Kuo SM. Enhanced apoptotic effects of dihydroartemisinin-aggregated gelatin and hyaluronan nanoparticles on human lung cancer cells. J Biomed Mater Res B Appl Biomater. 2014; 102: 455-62.

71. Dai L, Wang L, Deng L, Liu J, Lei J, Li D, et al. Novel multiarm polyethylene glycol-dihydroartemisinin conjugates enhancing therapeutic efficacy in non-small-cell lung cancer. Sci Rep. 2014; 4: 5871.

72. Hu YJ, Zhang JY, Luo Q, Xu JR, Yan Y, Mu LM, et al. Nanostructured Dihydroartemisinin Plus Epirubicin Liposomes Enhance Treatment Efficacy of Breast Cancer by Inducing Autophagy and Apoptosis. Nanomaterials (Basel). 2018; 8 .

73. Liu JJ, Tang W, Fu M, Gong XQ, Kong L, Yao XM, et al. Development of R8 modified epirubicin-dihydroartemisinin liposomes for treatment of non-small-cell lung cancer. Artif Cells Nanomed Biotechnol. 2019; 47: 1947-60.

74. Ju RJ, Cheng $\mathrm{L}$, Peng XM, Wang $\mathrm{T}$, Li CQ, Song $\mathrm{XL}$, et al. Octreotide-modified liposomes containing daunorubicin and 
dihydroartemisinin for treatment of invasive breast cancer. Artif Cells Nanomed Biotechnol. 2018; 46: 616-28.

75. Creek DJ, Chiu FCK, Prankerd RJ, Charman SA, Charman WN. Kinetics of iron-mediated artemisinin degradation: Effect of solvent composition and iron salt. J Pharm Sci-Us. 2005; 94: 1820-9.

76. Niitsu Y, Kohgo Y, Nishisato T, Kondo H, Kato J, Urushizaki Y, et al. Transferrin receptors in human cancerous tissues. Tohoku J Exp Med. 1987; 153: 239-43

77. Nakase I, Gallis B, Takatani-Nakase T, Oh S, Lacoste E, Singh NP, et al. Transferrin receptor-dependent cytotoxicity of artemisinin-transferrin conjugates on prostate cancer cells and induction of apoptosis. Cancer Lett. 2009; 274: 290-8

78. Singh NP, Lai H. Selective toxicity of dihydroartemisinin and holotransferrin toward human breast cancer cells. Life Sci. 2001; 70: 49-56.

79. Chen D, Chen C, Huang C, Chen T, Liu Z. Injectable Hydrogel for NIR-II Photo-Thermal Tumor Therapy and Dihydroartemisinin-Mediated Chemodynamic Therapy. Front Chem. 2020; 8: 251.

80. Jessmon P, Boulanger T, Zhou W, Patwardhan P. Epidemiology and treatment patterns of epithelial ovarian cancer. Expert Rev Anticancer Ther. 2017; 17: 427-37.

81. Chang A. Chemotherapy, chemoresistance and the changing treatment landscape for NSCLC. Lung Cancer. 2011; 71: 3-10.

82. Chen T, Li M, Zhang R, Wang H. Dihydroartemisinin induces apoptosis and sensitizes human ovarian cancer cells to carboplatin therapy. J Cell Mol Med. 2009; 13: 1358-70.

83. Zhou HJ, Zhang JL, Li A, Wang Z, Lou XE. Dihydroartemisinin improves the efficiency of chemotherapeutics in lung carcinomas in vivo and inhibits murine Lewis lung carcinoma cell line growth in vitro. Cancer Chemother Pharmacol. 2010; 66: 21-9.

84. Jin $\mathrm{H}$, Jiang AY, Wang H, Cao Y, Wu Y, Jiang XF. Dihydroartemisinin and gefitinib synergistically inhibit NSCLC cell growth and promote apoptosis via the Akt/mTOR/STAT3 pathway. Mol Med Rep. 2017; 16: 3475-81.

85. Shen R, Li J, Ye D, Wang Q, Fei J. Combination of onconase and dihydroartemisinin synergistically suppresses growth and angiogenesis of non-small-cell lung carcinoma and malignant mesothelioma. Acta Biochim Biophys Sin (Shanghai). 2016; 48: 894-901.

86. Zhao J, Pan Y, Li X, Zhang X, Xue Y, Wang T, et al. Dihydroartemisinin and Curcumin Synergistically Induce Apoptosis in SKOV3 Cells Via Upregulation of MiR-124 Targeting Midkine. Cell Physiol Biochem. 2017; 43: 589-601.

87. Hou JM, Wang DS, Zhang RW, Wang H. Experimental therapy of hepatoma with artemisinin and its derivatives: In vitro and in vivo activity, chemosensitization, and mechanisms of action. Clinical Cancer Research. 2008; 14: 5519-30.

88. Wang SJ, Gao Y, Chen H, Kong R, Jiang HC, Pan SH, et al. Dihydroartemisinin inactivates NF-kappaB and potentiates the anti-tumor effect of gemcitabine on pancreatic cancer both in vitro and in vivo. Cancer Lett. 2010; 293: 99-108.

89. Wu GS, Lu JJ, Guo JJ, Huang MQ, Gan L, Chen XP, et al. Synergistic anti-cancer activity of the combination of dihydroartemisinin and doxorubicin in breast cancer cells. Pharmacol Rep. 2013; 65: 453-9.

90. Tai X, Cai XB, Zhang Z, Wei R. In vitro and in vivo inhibition of tumor cell viability by combined dihydroartemisinin and doxorubicin treatment, and the underlying mechanism. Oncol Lett. 2016; 12: 3701-6.

91. Li X, Ba Q, Liu Y, Yue Q, Chen P, Li J, et al. Dihydroartemisinin selectively inhibits PDGFRalpha-positive ovarian cancer growth and metastasis through inducing degradation of PDGFRalpha protein. Cell Discov. 2017; 3: 17042.

92. Mi YJ, Geng GJ, Zou ZZ, Gao J, Luo XY, Liu Y, et al. Dihydroartemisinin inhibits glucose uptake and cooperates with glycolysis inhibitor to induce apoptosis in non-small cell lung carcinoma cells. PLoS One. 2015; 10: e0120426.

93. Zhang CZ, Pan Y, Cao Y, Lai PB, Liu L, Chen GG, et al. Histone deacetylase inhibitors facilitate dihydroartemisinin-induced apoptosis in liver cancer in vitro and in vivo. PLoS One. 2012; 7: e39870.

94. Wu L, Pang Y, Qin G, Xi G, Wu S, Wang X, et al. Farnesylthiosalicylic acid sensitizes hepatocarcinoma cells to artemisinin derivatives. PLoS One. 2017; 12: e0171840.

95. Wang B, Ni ZH, Dai XF, Qin LY, Li XZ, Xu L, et al. The Bcl-2/xL inhibitor ABT-263 increases the stability of Mcl-1 mRNA and protein in hepatocellular carcinoma cells. Mol Cancer. 2014; 13.

96. Yan X, Li P, Zhan Y, Qi M, Liu J, An Z, et al. Dihydroartemisinin suppresses STAT3 signaling and Mcl-1 and Survivin expression to potentiate ABT-263-induced apoptosis in Non-small Cell Lung Cancer cells harboring EGFR or RAS mutation. Biochem Pharmacol. 2018; 150: 72-85.
97. He Q, Shi J, Shen XL, An J, Sun H, Wang L, et al. Dihydroartemisinin upregulates death receptor 5 expression and cooperates with TRAIL to induce apoptosis in human prostate cancer cells. Cancer Biol Ther. 2010; 9: $819-24$

98. Korbelik M. Complement upregulation in photodynamic therapy-treated tumors: Role of Toll-like receptor pathway and NFkappaB. Cancer Lett. 2009; 281: 232-8.

99. Guo W, Imai S, Yang JL, Zou SP, Li HJ, Xu HK, et al. NF-KappaB Pathway Is Involved in Bone Marrow Stromal Cell-Produced Pain Relief. Front Integr Neurosc. 2018; 12.

100. Li YJ, Zhou JH, Du XX, Jia de X, Wu CL, Huang $P$, et al. Dihydroartemisinin accentuates the anti-tumor effects of photodynamic therapy via inactivation of NF-kappaB in Eca109 and Ec9706 esophageal cancer cells. Cell Physiol Biochem. 2014; 33: 1527-36.

101. Li Y, Sui H, Jiang C, Li S, Han Y, Huang P, et al. Dihydroartemisinin Increases the Sensitivity of Photodynamic Therapy Via NF-kappaB/HIF-1alpha/VEGF Pathway in Esophageal Cancer Cell in vitro and in vivo. Cell Physiol Biochem. 2018; 48: 2035-45.

102. Guo S, Yao X, Jiang Q, Wang K, Zhang Y, Peng $H$, et al. Dihydroartemisinin-Loaded Magnetic Nanoparticles for Enhanced Chemodynamic Therapy. Front Pharmacol. 2020; 11: 226.

103. Feng $\mathrm{X}, \mathrm{Li} \mathrm{L}$, Jiang $\mathrm{H}$, Jiang K, Jin Y, Zheng J. Dihydroartemisinin potentiates the anticancer effect of cisplatin via mTOR inhibition in cisplatin-resistant ovarian cancer cells: involvement of apoptosis and autophagy. Biochem Biophys Res Commun. 2014; 444: 376-81.

104. Luo QY, Lai YH, Liu SK, Wu M, Liu Y, Zhang ZZ. Deregulated expression of DNA polymerase beta is involved in the progression of genomic instability. Environ Mol Mutagen. 2012; 53: 325-33.

105. Chen H, Gu S, Dai H, Li X, Zhang Z. Dihydroartemisinin Sensitizes Human Lung Adenocarcinoma A549 Cells to Arsenic Trioxide via Apoptosis. Biol Trace Elem Res. 2017; 179: 203-12.

106. Kong R, Jia G, Cheng ZX, Wang YW, Mu M, Wang SJ, et al. Dihydroartemisinin enhances Apo2L/TRAIL-mediated apoptosis in pancreatic cancer cells via ROS-mediated up-regulation of death receptor 5. PLoS One. 2012; 7: e37222.

107. Veerappan A, Eichhorn T, Zeino M, Efferth T, Schneider D. Differential interactions of the broad spectrum drugs artemisinin, dihydroartemisinin and artesunate with serum albumin. Phytomedicine. 2013; 20: 969-74.

108. Ericsson T, Sundell J, Torkelsson A, Hoffmann KJ, Ashton M. Effects of artemisinin antimalarials on Cytochrome P450 enzymes in vitro using recombinant enzymes and human liver microsomes: potential implications for combination therapies. Xenobiotica. 2014; 44: 615-26.

109. Ribeiro IR, Olliaro P. Safety of artemisinin and its derivatives. A review of published and unpublished clinical trials. Med Trop (Mars). 1998; 58: $50-3$

110. Adjuik M, Babiker A, Garner P, Olliaro P, Taylor W, White N, et al. Artesunate combinations for treatment of malaria: meta-analysis. Lancet. 2004; 363: 9-17.

111. Dayan AD. Neurotoxicity and artemisinin compounds do the observations in animals justify limitation of clinical use? Med Trop (Mars). 1998; 58: 32-7.

112. Hosoya K, Couto CG, London CA, Kisseberth WC, Phelps MA, Dalton JT. Comparison of High-Dose Intermittent and Low-Dose Continuous Oral Artemisinin in Dogs With Naturally Occurring Tumors. J Am Anim Hosp Assoc. 2014; 50: 390-5.

113. Jansen FH, Adoubi I, Comoe JCK, De Cnodder T, Jansen N, Tschulakow A, et al. First Study of Oral Artenimol-R in Advanced Cervical Cancer: Clinical Benefit, Tolerability and Tumor Markers. Anticancer Res. 2011; 31: $4417-22$

114. von Hagens C, Walter-Sack I, Goeckenjan M, Osburg J, Storch-Hagenlocher B, Sertel S, et al. Prospective open uncontrolled phase I study to define a well-tolerated dose of oral artesunate as add-on therapy in patients with metastatic breast cancer (ARTIC M33/2). Breast Cancer Res Tr. 2017; 164: 359-69.

115. Krishna S, Ganapathi S, Ster IC, Saeed MEM, Cowan M, Finlayson C, et al. A Randomised, Double Blind, Placebo-Controlled Pilot Study of Oral Artesunate Therapy for Colorectal Cancer. Ebiomedicine. 2015; 2: 82-90.

116. Ericsson T, Blank A, von Hagens C, Ashton M, Abelo A. Population pharmacokinetics of artesunate and dihydroartemisinin during long-term oral administration of artesunate to patients with metastatic breast cancer. Eur J Clin Pharmacol. 2014; 70: 1453-63.

117. Konig M, von Hagens C, Hoth S, Baumann I, Walter-Sack I, Edler L, et al. Investigation of ototoxicity of artesunate as add-on therapy in patients with metastatic or locally advanced breast cancer: new audiological results from a prospective, open, uncontrolled, monocentric phase I study. Cancer Chemoth Pharm. 2016; 77: 413-27. 
118. Martello LA, McDaid HM, Regl DL, Yang CP, Meng D, Pettus TR, et al. Taxol and discodermolide represent a synergistic drug combination in human carcinoma cell lines. Clin Cancer Res. 2000; 6: 1978-87. 